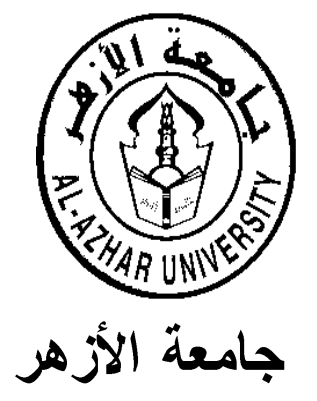

كلية الثريعة والقانون بأسيوط

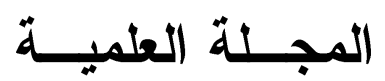

\title{
ضجعة الفهر
}

\section{هفهومها ـ صفتها ـ هملها ـ مكمها}

$$
\begin{aligned}
& \text { إعداد } \\
& \text { أ. د د/ خالد بن أحمد بن حسن بإبطبن } \\
& \text { أستاذ الفقه بكلية الثريعة والدراسات الإسلامية }
\end{aligned}
$$

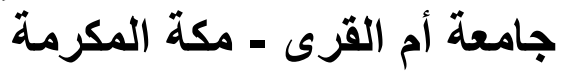

( العدد الثاني والثلاثون الإصدار الثاني يوليو • r • ب م الجزء الثاني ) 


$$
\text { ضجعة الفـــر : مفهومها - صفتها - محلها - حكمها }
$$

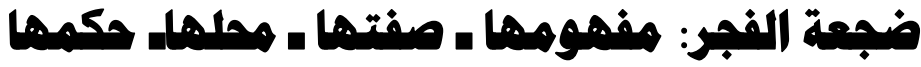

خالا بن أحمد بن حسن بابطين. قسم الفقه، كلية الثريعة والار اسات الإسلامية، جامعة أم القرى، مكة المكرمة، المملكة العربية السعودية.

\section{Dr.khaled.babtain@gmail.com البريد الاكتروني:}

\section{مط:مص البمث}

وهو من لطائف العلم والفقه، بحيث إنه يلقي الضوء على هذه المسألة، ويُفنِّ أقوال أهل

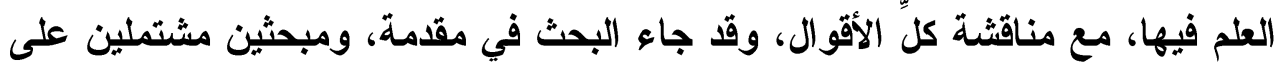
عدة مطالب، ثم خاتمة مذيلة بقائمة المصادر والمراجع. أما المقدمة: فذكرت فيها خطة وفئ

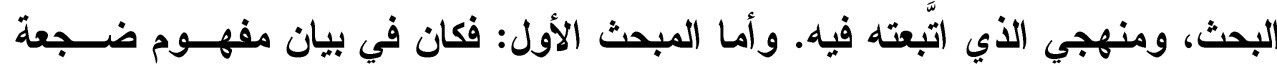
القجر وصفتها ومحلّها وحكمها، وقد جاء هذا المبحث في خمسة مطالب. أولها: مفهوم

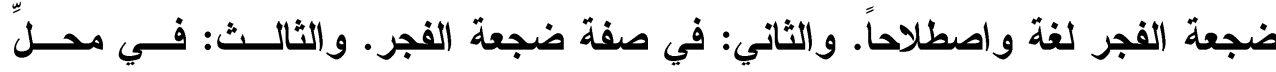
ضجعة الفجر • والر ابع: في الحكمة من ضجعة الفجر • والخامس: عبارة عـن تســاؤل؛ هل يشرع لضجعة الفجر ذكر مخصوص؟؟، وأما المبحث الثاني: فكان في بيـان أقــوال

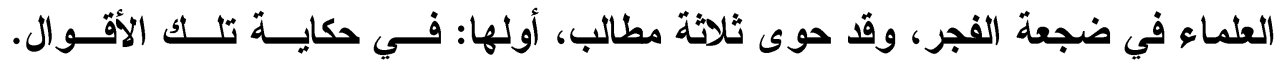
والثاني: في مناقشة تلك الأقوال. والثالث: في الترجيح بين تلك الأقوال، وأمســ خاتمـــة البحث: ففيها أبرز نتائج البحث، ومنها: أن أهل العلم في ضجعة الفجر طرفان وواسطة والهي

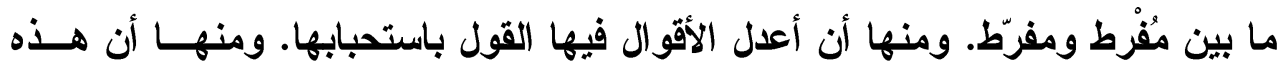
الضجعة ضجعة لطيفة تكون بين راتبة الفجر والصبح. ومنها أن محلها البيت ولـيس بليس المسجد، وأنه ليس لها ذكر مخصوص.

الككمات الافتتاصية: ضجعة، حكم الاضطجاع، صلاة الفجر، راتبة الفجر. 


$$
\text { ضجعة الفـــر : مفهومها - صفتها - محلها - حكمها }
$$

Lying on the right side after performing the Sunnah of the Dawn Prayer (daj s at ul-fajr): its concept, characteristics, place, and legal ruling

Khaled bin Ahmed bin Hasan Babtain.

Department of Jurisprudence, College of Sharia and Islamic Studies, Umm Al-Qura University, Makkah AlMukarramah, Kingdom of Saudi Arabia.

Email: Dr.khaled.babtain@gmail.com.

Abstract:

This paper sheds light on an issue which is considered one of the subtleties of knowledge and jurisprudence; it discusses and refutes scholars' views on this issue. This paper consists of an introduction, two sections including some subsections thereunder and a conclusion followed by a bibliography of sources and references. The introduction presents the research plan and the approach adopted in the paper. The first section explores the concept of $d a j^{\varsigma}$ at $u l$-fajr (lying on the right side after performing the Sunnah of the Dawn Prayer), its characteristics, place and legal ruling. This section incorporates five subsections. The first subsection explores the linguistic and Sharia-based technical definitions of the concept of $d a j^{\varsigma}$ at ul-fajr. The second one explains the form and characteristics of $d a j^{\varsigma}$ at ul-fajr. The third one discusses the place of $d a j^{\varsigma}$ at $u l-f a j r$. The fourth one highlights the rationale of $d a j^{\varsigma}$ at ul-fajr. 


$$
\text { ضجعة الفــر : مفهومها - صفتها - محلها - حكمها }
$$

The fifth one addresses some questions that arise about this issue, such as whether it is recommended to say certain zhikr (God remembrance) for $d a j^{\varsigma}$ at ul-fajr. The second section explores the views of the scholars on $\mathrm{daj}^{\varsigma}$ at $u l$-fajr. This section incorporates three subsections. The first subsection provides the scholars' views. The second one discusses these views. The third one evaluates and grades these views. The conclusion highlights the most remarkable results of the research, including the fact that the views of Sharia scholars on $d a j^{\varsigma}$ at $u l-f a j r$ have been divided into several groups on a continuum with two extremes, but the most equitable opinion is that it is recommended. $d a j^{\varsigma}$ at $u l-f a j r$ is a state of quiet peaceful position of lying dawn that one could enjoy between the regular supererogatory two-unit Sunnah prayer and the obligatory two-unit Dawn Prayer. The place of $d a j^{s}$ at $u l$ fajr is the home not the mosque. This $d a j^{\varsigma}$ at ul-fajr has no specific statements of God remembrance.

Keywords: $\mathrm{Daj}^{\varsigma}$ at ul-fajr (lying on the right side after performing the Sunnah of the Dawn Prayer)، legal ruling of $d a j^{\varsigma}$ at ul-fajr، Dawn Prayer، The regular supererogatory two-unit Sunnah prayer of Dawn. 


$$
\text { ضجعة الفـــر : مفهومها - صفتها - محلها - حكمها }
$$

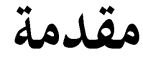

إنَّ الحمد الله، نحمده ونستعينه ونستغفره، ونعوذ بالله من شرور أنفسنا، ومن

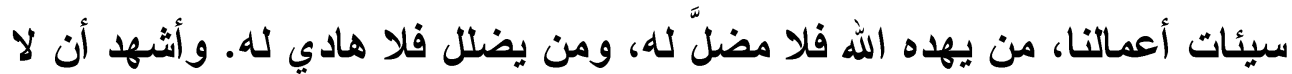

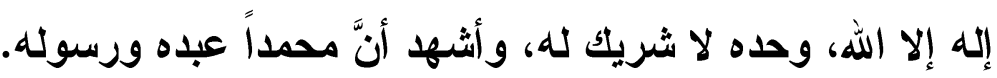

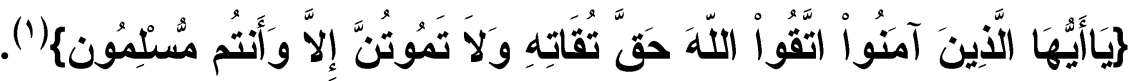

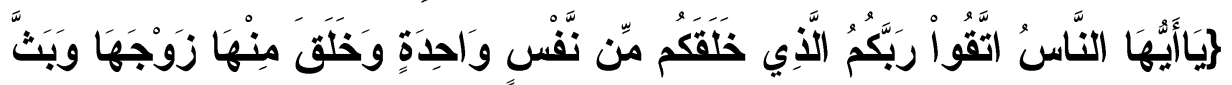

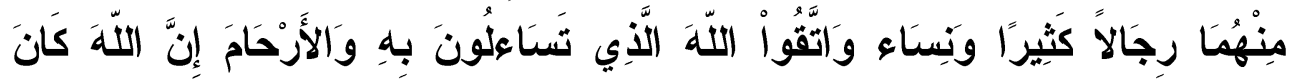

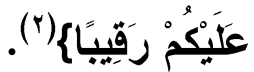

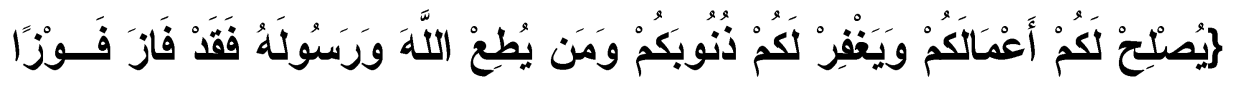
عَظِيمًا وبعد: فهذا بحث في موضوع لطيف، في مسألة تطرَّق إليها أهل العلم والفقه،

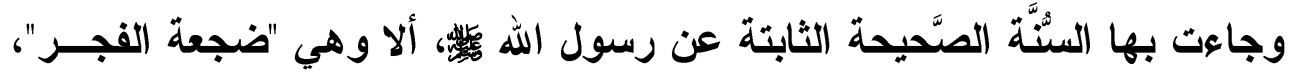

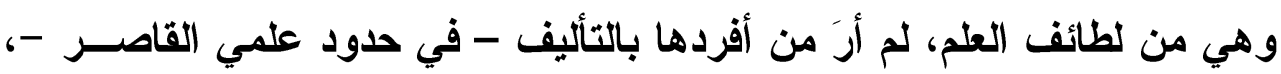
فعزمت على أن أكتب فيها، وأُلقي الضو هن عَ علئها.

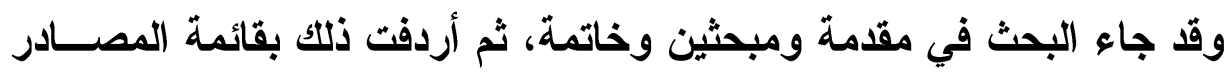

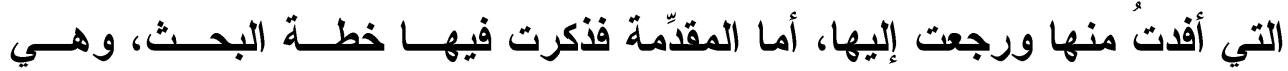

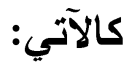

$$
\begin{aligned}
& \text { (1) سورة آل عمران: آية ץ. } 1 .
\end{aligned}
$$

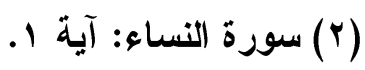

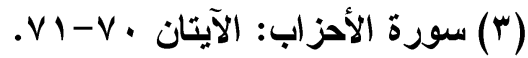




$$
\text { ضجعة الفــجر : مفهومها - صفتها - محلها - حكمها }
$$

البمث الأول :ضجعة الفجر: مفهومها وصفتها ومحلها * وفيه خمسة مطالب: الاملب الأول: مفهوم ضجعة الفجر لغة واصطلاحاً. الالماب الثاني: صفة ضجعة الفجر . الامطب الثالث: محل ضجعة الفجر. الامطب الرابع: الحكمة من ضجعة الفجر. الاملب الفامس: هل يشرع لضجعة الفجر ذكر مخصوص. المبمث الثاني : أقوال العلماء في ضجعة الفجر

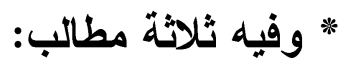
الامطب الأول: حكاية أقوال أهل العلم وأدلتهم. الالبا الثاني: مناقثة الأقو ال. الامطب الثالث: الترجيح. الفاتمة: وذكرث فيها أبرز نتائج البحث. * وقد أسميته: 》ضجعة الفجر: مفهومها - صفتها - محلها - حكمهاه، والله أرجو التوفيق والسداد، وأن يكون عملاً متقبلاً عنده، نافعاً لي في الارين. " منسمج البمث : سرت في بحثي على منهج علمي ثمثَّل في الأمور الآتية : 1 - جمعت المادة العلمية في البحث من مصادرها الأصيلة. r - ذكرت الخلاف في المسألة، مع إيراد أدلة كلِّ فريق حسب الإمكان. r - أوردت وجه الدلالة من كلّ دليل أسوقه. ع - جعلت ما نقلته من أقوال أهل العلم بالنــص بين علامتـي التتصــيص

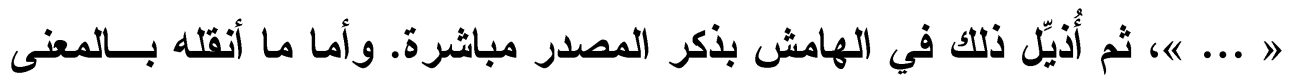




$$
\text { ضجعة الفـــر : مفهومها - صفتها - محلها - حكمها }
$$

فإني لا أجعله بين علامتي التنصيص، ثم أُذْيّل ذلك في الهامش بعبارة: 》انظــر: كذا ....

ه - وثُّقت الأقو ال و المذاهب و النصوُوص من مصادر ها الأصيلة. 1 - - عزوت الآيات القرآنية إلى مواضعها في القرآ آن العظيم، ملتزماً بإير ادها بالرسم العثماني، مع ذكر اسم السورة ورقم الآية عقب الاستثهاد بها. V - خرَّبت الأحاديث والآثار الواردة في البحث من مصادر السنة المعتمدة،

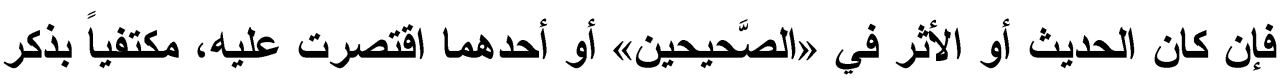
الجزء والصفحة ورقم الحديث. وإن كان في غيرهما من 》الستُننه فإني أحساول نقل تصحيح أو تضعيف علماء الحديث والمشتثلين بالسئَّة له. 1 - عرَّقت بالمصطلحات الفقهية. 9 - عُنيت عناية فائقة بشرح الكلمات الغريبة من مصادرها. . 1 - لم أُترجم لأحل من الأعلام طلباً للاختصار.

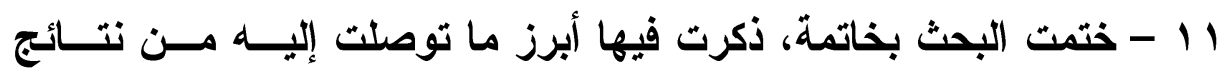

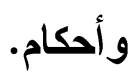

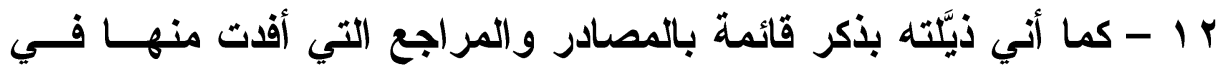




$$
\text { ضجعة الفـــر : مفهومها - صفتها - محلها - حكمها }
$$

\section{الإبمث الأول

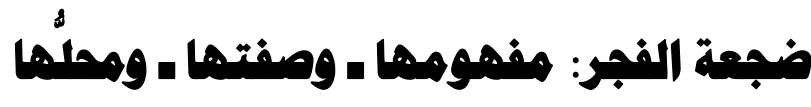 \\ * وفيه خمسة مطالب :}

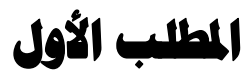

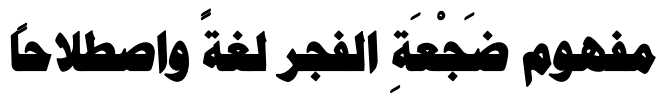

أولاً: مفهومهما لغةة:

الضَّجْعة - بفتح المعجمة - - المرة. والضِّجْعة - بالكسر - - الهريئة(1).

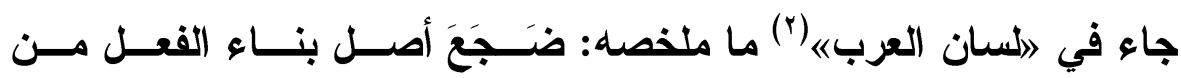

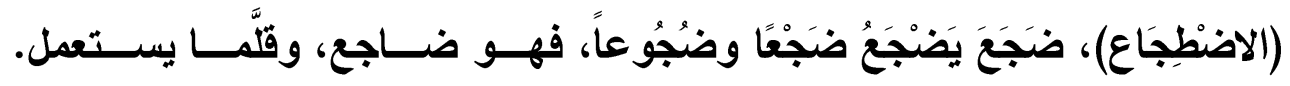

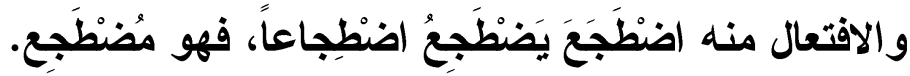

و(اضْطَجَعَ): نام. وقيل: استلقى ووضع جنبه بالأرض.

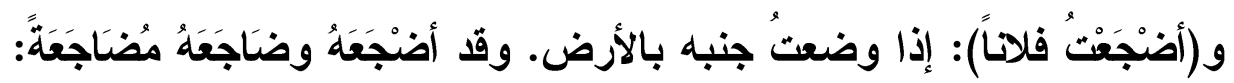

اضُطَجَعَ معهد.

و(ضَاجَعَ الرجل جاريته): إذا نام معها في شعار واحد، وهو ضجيعها، وهـي

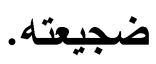

و(الضَّجْعَة): هيئة الاضطجاع. والمضنَجِع: جمع المضُجْعَ.

و(الاضْطِجَاع في الستُجود): أن يتضامّ ويلصق صدره بـــالأرض، وإذا قــالوا:

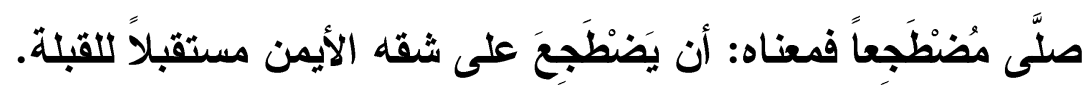

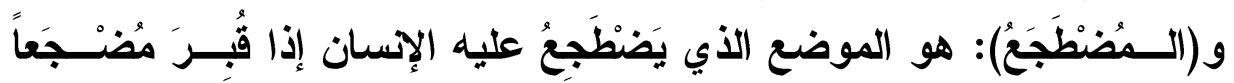

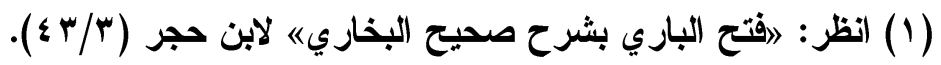

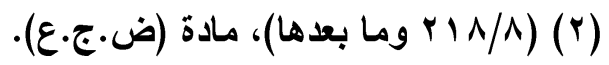




$$
\text { ضجعة الفـــر : مفهومها - صفتها - محلها - حكمها }
$$

على يمينه.

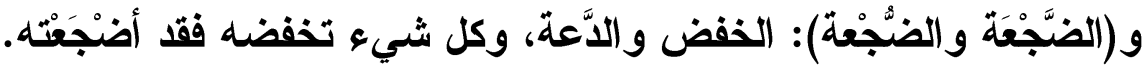

ثانيا: مفهومها اصطبامكا: يمكن تعريف ضجعة الفجر في الاصطلاح بأنها: ضجعة لطيفة(') يستلقي فيها من صلَّى الراتبة بعد أذان الفجر الصادق بوضع جنبه الأيمن على الأرض، ويكون

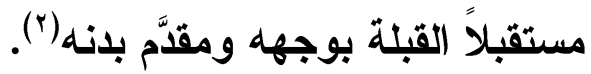
فقولنا: لطيفة، بمعنى خفيفة؛ لأن المضطَّجع لا يستغرق في اضطجاعه، وإنما بمقدار ما يستريح أو يفصل ما بين الر اتبة والفريضة. وقولنا: بعد أذان الفجر الصادق؛ لأنه الوارد في حـــيث عائشــة رضـــي الله

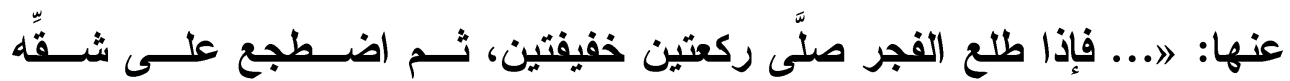

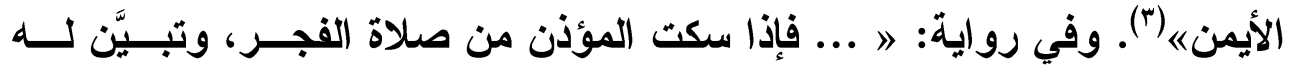

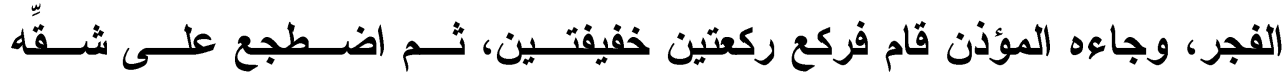
الأيمنه(أ)

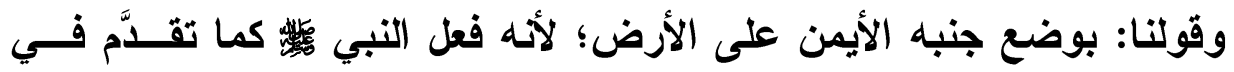

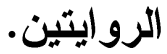
وقولنا: مستقبلاً القبلة بوجهه ومقدَّم بدنه؛ لأن هذه الهريئة هي هيأسـة مــن

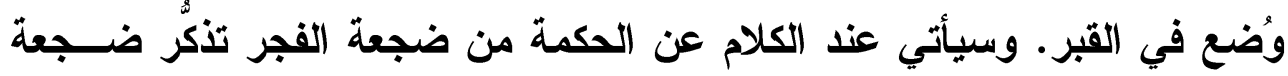
(القبر

(1) انظر: 》نهاية الزينه لمحمد عمر نووي الجاوى (ص 1 + 1).

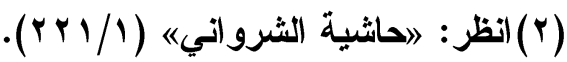

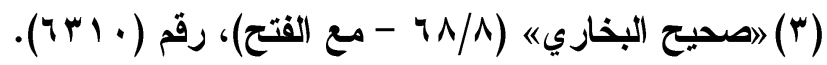

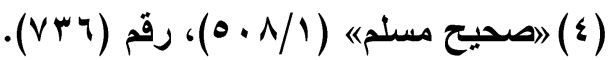




$$
\text { ضجعة الفـــر : مفهومها - صفتها - محلها - حكمها }
$$

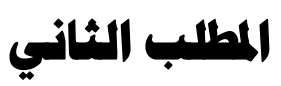 \\ صفة فمعة الفمر}

تقدَّم في التعريف بها أن المضطبع يضع جنبه على شقه الأيمن، والأصل فيه ما روته عائشة رضي الله عنها في الأحاديث المتقدمة. وقد بوَّب عليــه الإمــام

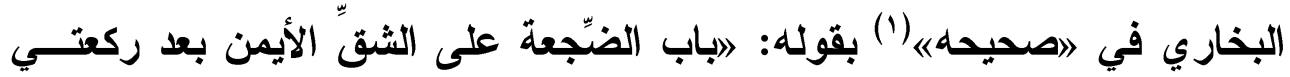
الفجر). قال الحافظ ابن حجر: اوفيه أن الاضطجاع إنما يتم إذا كان على الثــق الأيمنه(ץ). وقال أبو زرعة العراقي: 》فيه أن الاضطجاع المستحب بعد ركعتـي الإني

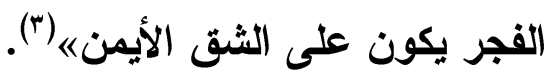

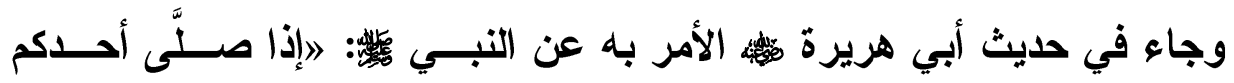

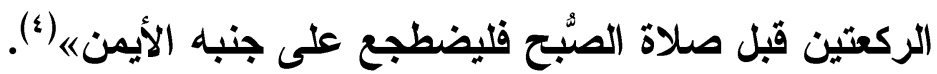
قال ابن القيم - رحمه الله تعالى -: الاوفي اضطجاعه على شقه الأيمن ســرّ، وهو أن القلب معلَّق في الجانب الأيسر، فإذا نام على الجنب الأيسر استثقل نوماً، لأكها يكون في دعة واستراحة فيثقل نومه، فإذا نام على شقه الأيمن فإنه يقلـق ولا يستغرق في النوم لقلق القلب، وطلبه مستقره وميله إليه، ولهـــا اســتحب

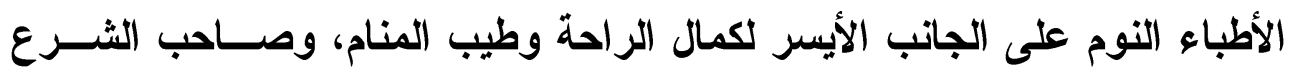
يستحب النوم على الجانب الأيمن؛ لئلا يثقل نومه فينام عن قيام الليـل، فــالنوم

$$
\begin{aligned}
& \text {. } \\
& \text { (فتح الباري)《 (r/r) }
\end{aligned}
$$

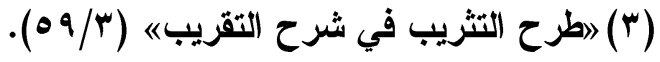

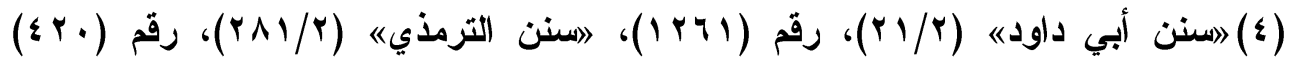

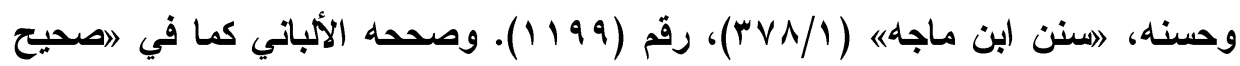

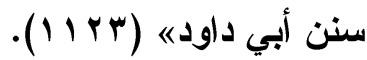




$$
\text { ضجعة الفـــر : مفهومها - صفتها - محلها - حكمها }
$$

على الجانب أنفع للقلب، وعلى الجانب الأيسر أنفع للبدنه(1). ويذهب الثافعية - وهم ممن يرى سنية الضَّجعة مطلقاً كما ســيأتي - إلـى أنها تحصل بأي كيفية كاتت، والأولى كونها على الهيئة التي يكون عليها الإنسان

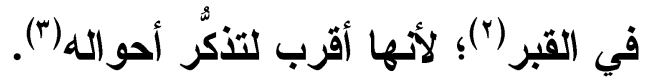

واختلفوا هل يحصل أصل السنة بالاضطجاع على الشق الأيسر أو لا؟

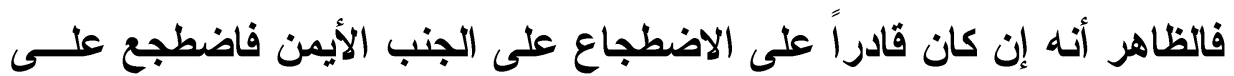

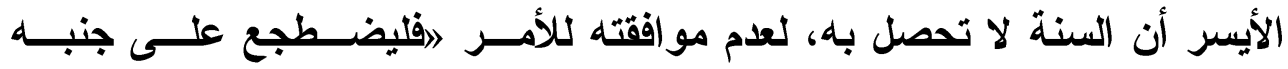

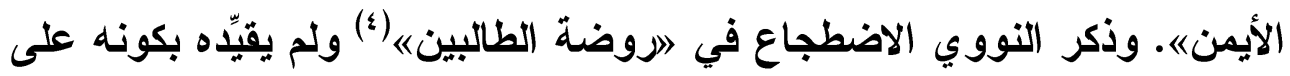
الجانب الأيمن، ومقتضى ما أثشار إليه أن السنة تحصل بالأمرين! أمـــا إن كــان

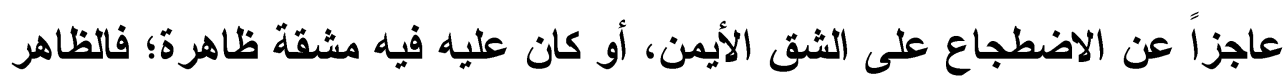
الأتقال للثق الأيسر (•).

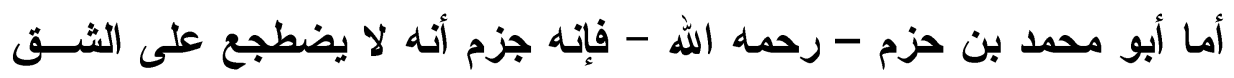
الأيسر مطلقاً، وإنما يشير إلى الاضطجاع للثق الأيمن إثارة. ونصٌٌ عبارته في

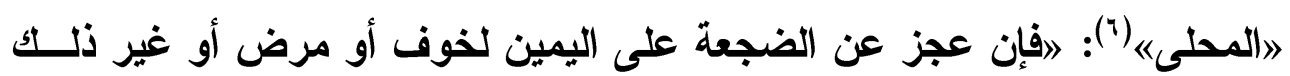
أشار إلى ذلك حسب طاقته فقطه .

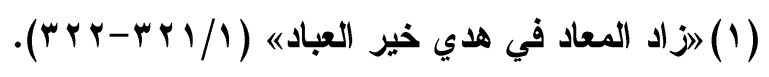

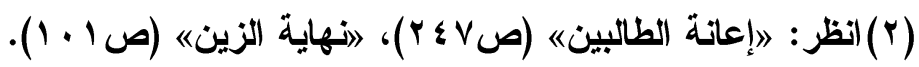

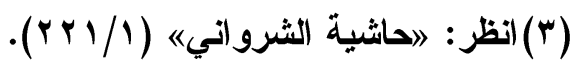

$$
\begin{aligned}
& \text {. }(\varepsilon \varepsilon \cdot 1)(\varepsilon)
\end{aligned}
$$

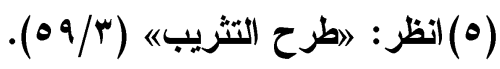

$$
\begin{aligned}
& \text {. (Y YN/Y)( ( ) }
\end{aligned}
$$




$$
\text { ضجعة الفـــر : مفهومها - صفتها - محلها - حكمها }
$$

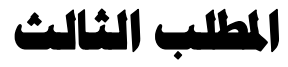

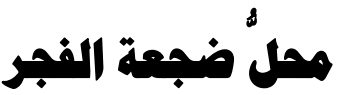

الكلام في هذا المطلب في فرعين، الأول: في الوقت الأي يضطبع فيه.

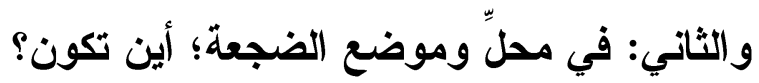

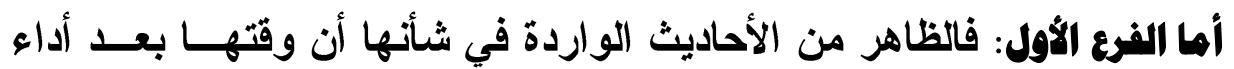

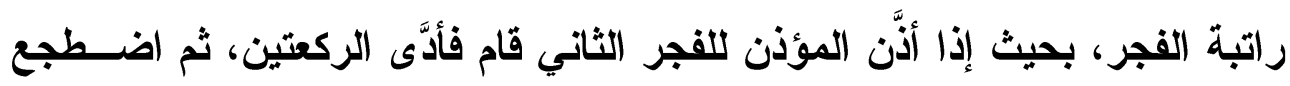
على جنبه الأيمن كما تقدَّم، فتكون بين السنة و الفريضة. وعلى هذا؛ فـــإذا أخَّهر

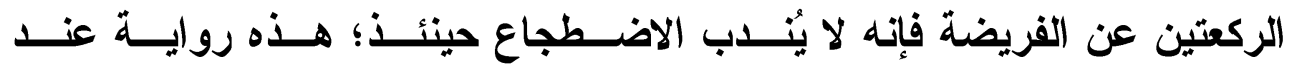

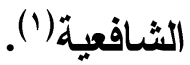

وعند جماعة من الشافعية أن الضجعة مندوبة مطلقاً، سواء قــدَّم الــركعتين

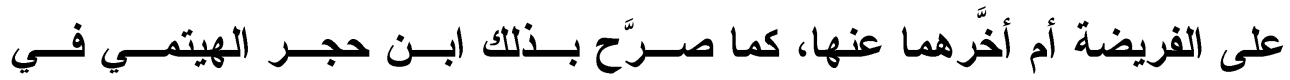

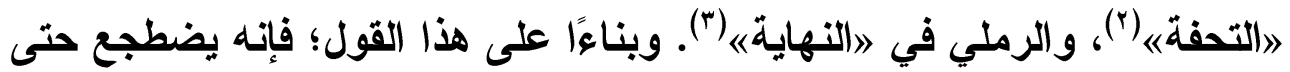

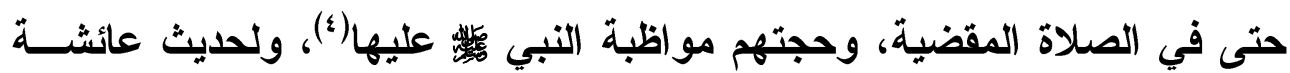
رضي الله عنها: اركعتا الفجر خير من الانيا وما فيها《(•). قلت: وهذا خلاف الظاهر؛ لأن الغرض من الاضطجاع - عندهم - الفصل بين

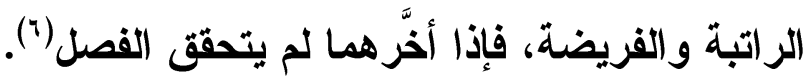

(1) (انظر : 》إعانة الطالبين《) (صV § ؟).

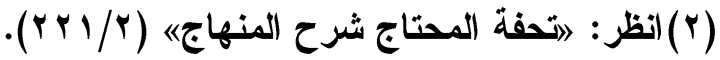

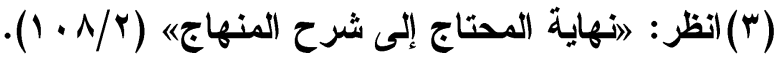

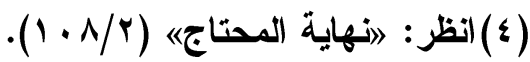

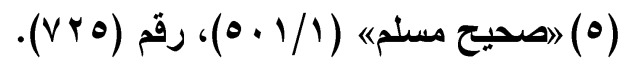

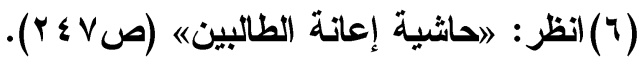




$$
\text { ضجعة الفـــر : مفهومها - صفتها - محلها - حكمها }
$$

\section{الفرع الثاني: أين يضطجع هذا الضجعة؟}

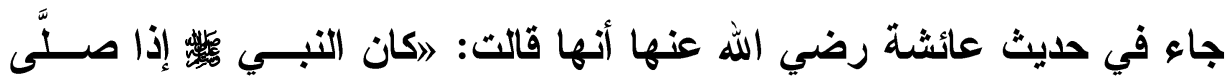

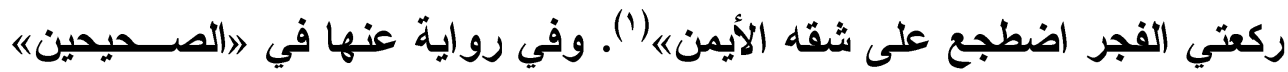

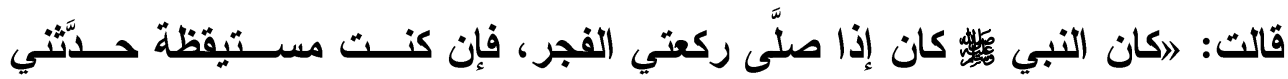

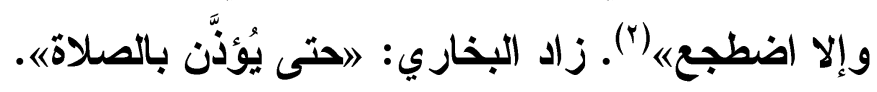

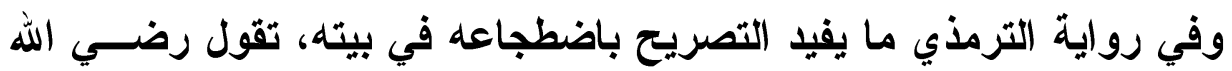

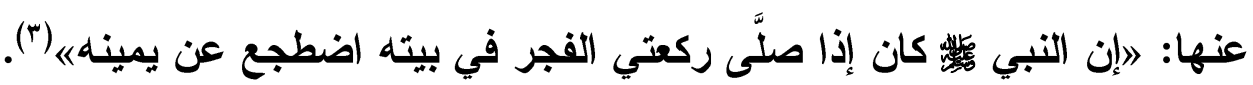

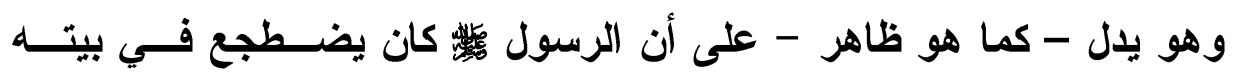
وحُجُر اته، وقد جزم بذلك العلامة العُشيمين (4).

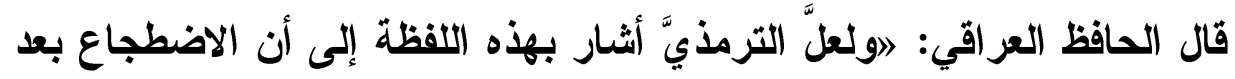

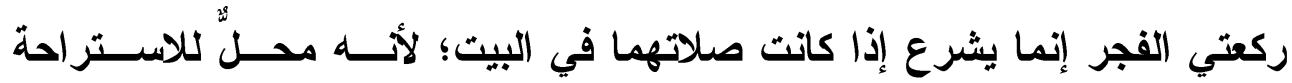

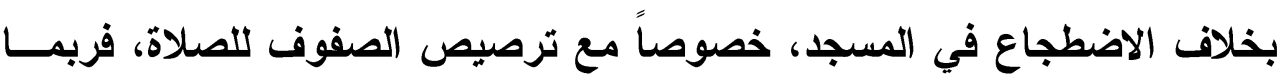

استُقبح ذلك في المسجده (ه).

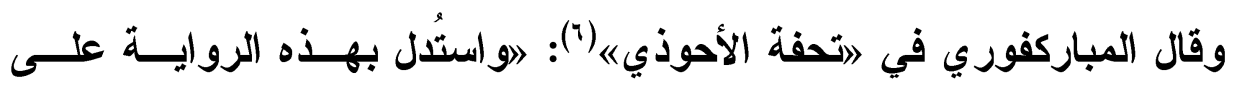
استحباب الاضطجاع في البيت دون المسجد، وهو محكيٌّ عن ابن عمر، وقهـوَّاه

$$
\text { (1) (صحيح البخاري) (. (119 - مئ الفتح). }
$$

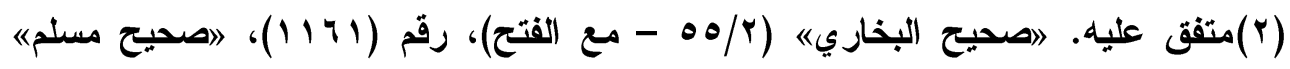
( ) و اللفظ لمسلم.

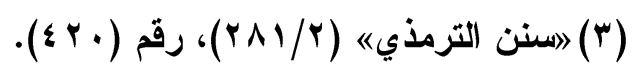

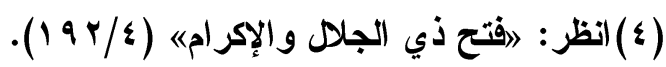

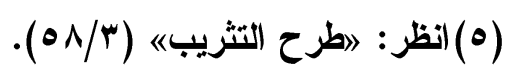

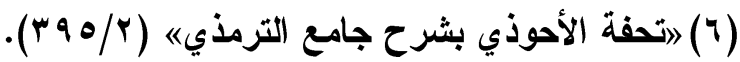




$$
\text { ضجعة الفـــر : مفهومها - صفتها - محلها - حكمها }
$$

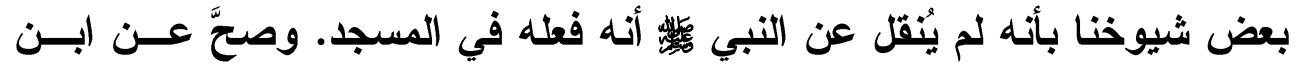

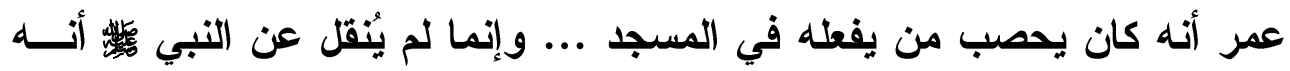
فعله في المسجد؛ لأنه كان يصلّي سنة الفجر في البيث فكان يضطبع في البيثه.

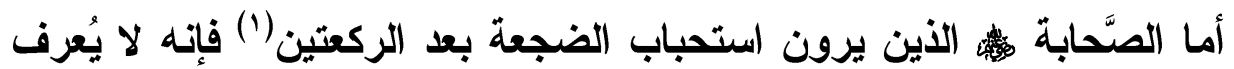

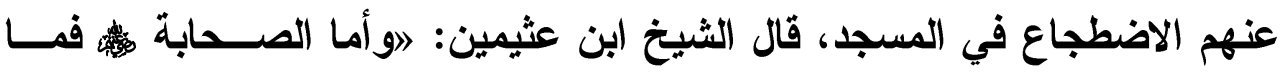

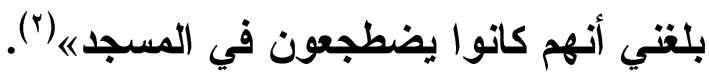
أما ما ذكره ابن حزم عن عثمان بن غيَّاث قال: 》كان الرجل يجيء وعمر بن الخطاب يصلّي بالناس الصبح، فيصلِّي ركعتين في مؤخر المسجد، ويضع جنبــه

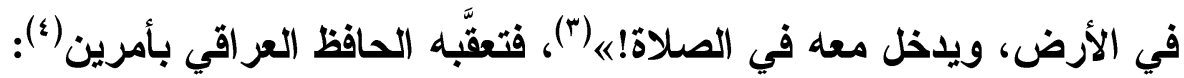

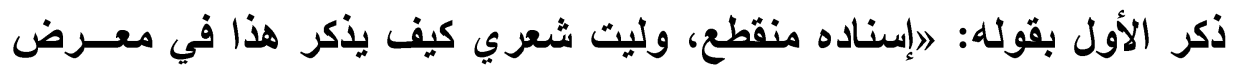
الاحتجاج به أو الاستشهاد به وهو لا يعرف من كان يفعلهـ. والثاني: بأنه لو عُرف أن الأين فعلوه من الصحابة فلا حجة في فعلهم مــع

مخالفته للحديث الصحيح: 》إذا أُقيمت الصلاة فلا صلاة إلا المكتوبة)|(ه).

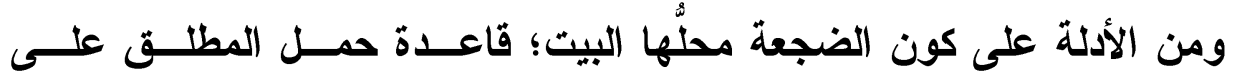

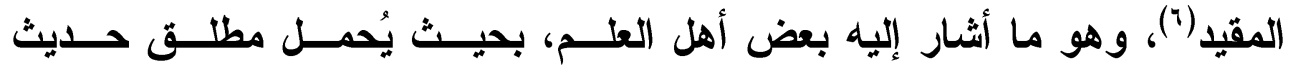

(1) (1) (1)

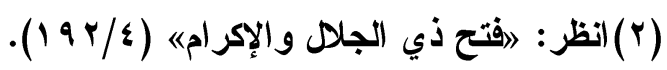

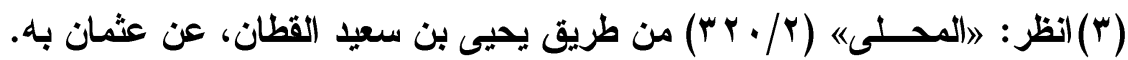

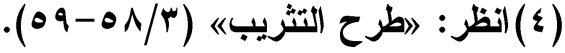

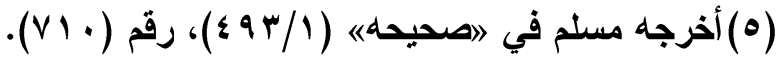

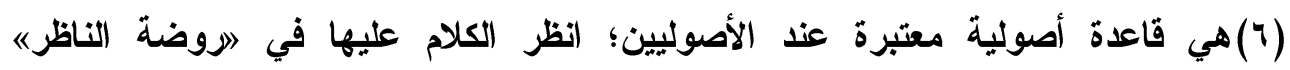

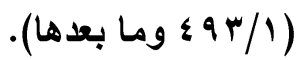




\section{ضجعة الفـــر : مفهومها - صفتها - محلها - حكمها}

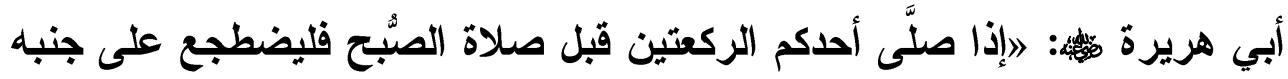

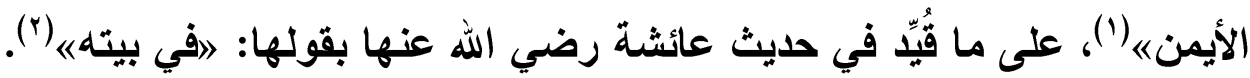

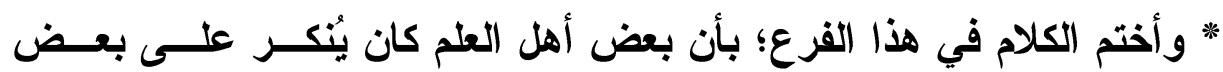
العماء فعل الاضطجاع بالمسجد كما ذكره الحافة العراقي(") لأن الأصل في أداء راتبة الفجر أن تكون في البيت فيمكن الضجعة والاستراحة فيه، أما في المساجد بعد الأذان فلا يحسن فعلها! وقد أثثار العلاَّمة العُثيمين - رحمه الله - أن بعض الإخوان الـــين يــرون استحباب هذه الضجعة كانوا يفعلون ذلك في المسجد - والظاهر أن ذلك كان في القصيم -، كان إذا صلَّى سنة الفجر اضطجع على جنبه الأيمن، لكنه أفاد أن ذلك الفعل قد انقطع ولم يعد موجوداً (؛)، وبالله التوفيق.

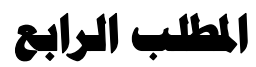

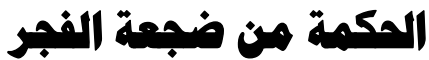

أثشار بعض فقهاء الثافعية إلى الحكمة من مشروعية ضجعة الفجر؛ لأنهـــ يرون استحبابها مطلقاً كما سيأتي، وما ذكروه لا يخرج عن ثلاثة أشياء:

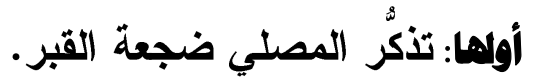
الأمر الأي يبعث في نفسه الهمّة للزيادة من الأعمال الصالحة والنشاط فـي

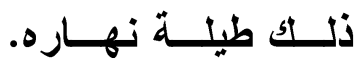

$$
\begin{aligned}
& \text { (1) (1) تقدَّم تخريجه. }
\end{aligned}
$$

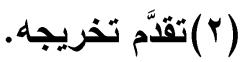

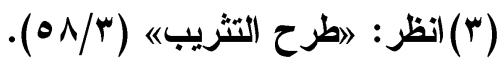

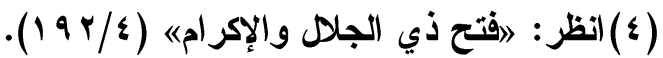


ضجعة الفــجر : مفهومها - صفتها - محلها - حكمها

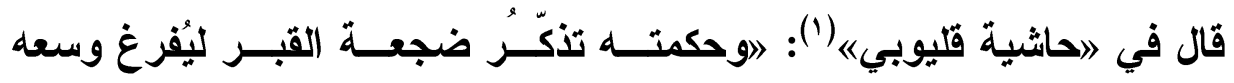
في الأعمال الصالحة أول النهاره).

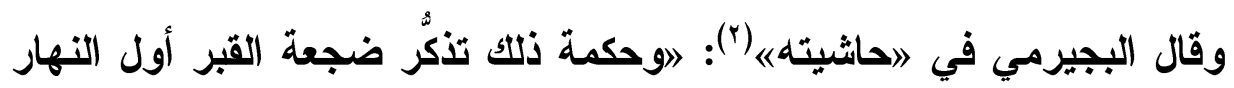
ليكون باعثاً له على أعمال الآخرة، أو لإظهار العجز في أول النهارهـ. ثانيها: الاستر احة والاستجمام لمن قام الليل ليقوم نشيطاً لصلاة الفجر.

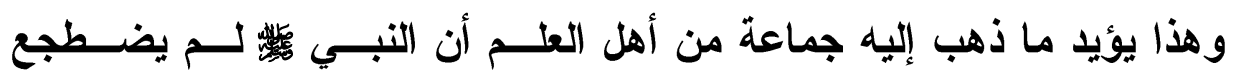
إلا ليستريح به، وليس لأنه فعله ليُستنَّ به عليه الصلاة والسلام(ّ)، وهو اختيار

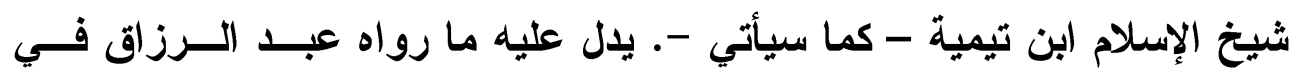

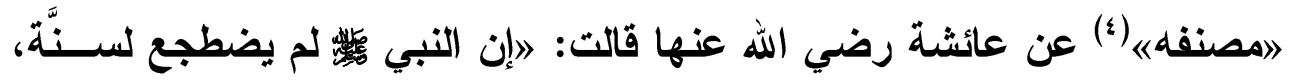
ولكنه كان يأب ليله فيستريحه. ولأن الأي يقوم عند أذان الفجر يكون قد شبع من النوم، أما إذا كان لم يــــم أو متعباً إذا نام يستمر فلا يقوم، وفرق بين من يقوم الليل ومن كان على سهره، فالأي يقوم الليل يكون في آخر الليل نشطاً؛ لكن هذا الأي لم يقــم إلا بعـــ أذان الفجر من أجل أنه لم ينم إلا في آخر الليل فإنه سيقى على كسله حتى لــو قــام

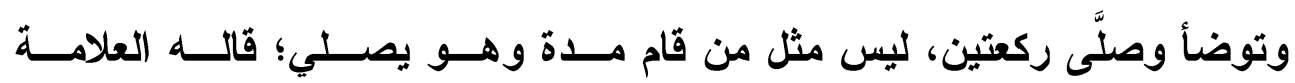
(العُثْيمين (•)

$$
\begin{aligned}
& .(r \varepsilon \cdot / 1)(1) \\
& .(\varepsilon r 1 / 1)(r)
\end{aligned}
$$

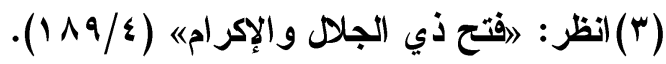

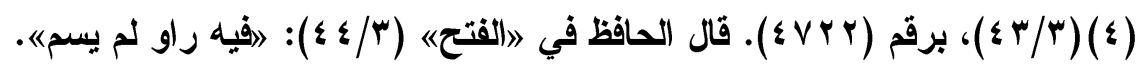

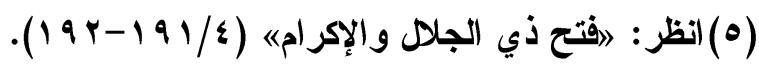


ضجعة الفــجر : مفهومها - صفتها - محلها - حكمها

ثالثها: الفصل بين ركعتي الفجر وصلاة الصنّبح(').

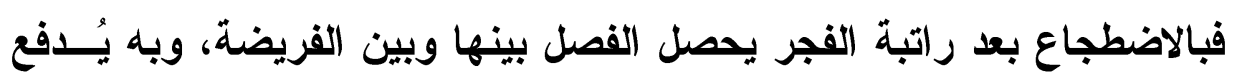
توهُّم أن صلاة الصبح رباعية(؟). وعليه؛ فمن ذهب إلى الفصل قال: لا اختصاص للضَّجعة، ولهذا قال الثـافعية: اتتأدَّى السنة بكل ما يحصل به الفصل، من مشي،

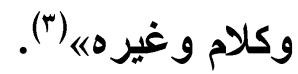

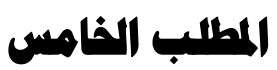

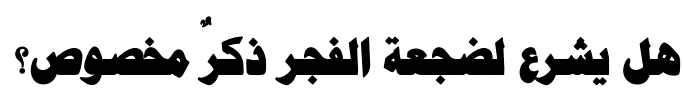

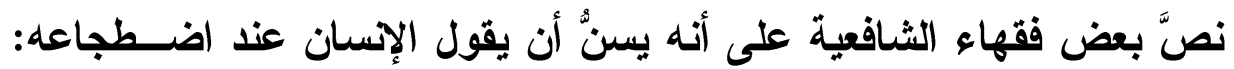

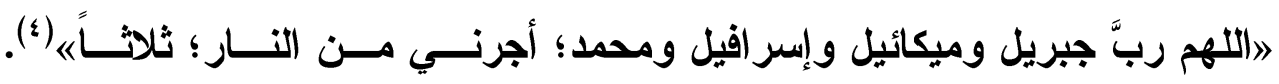
واحتجوا بما رواه الطبراني في 》المعجم الكبير)(•) من طريث مبشـر بـن أبسي

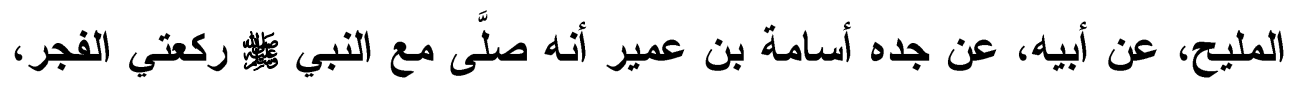
فصلَّى قريباً منه، فصلَّى ركعتين خفيفتين فسمعته يقول: ... فنكره إلا أنه قال في آخره: 》أعوذ بك من الناريه. وهو غير صالح للاحتجاج، في إسناده يحيى بن أبي

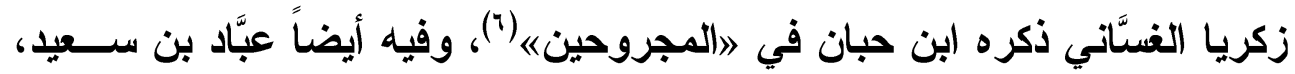

$$
\begin{aligned}
& \text { (1) انظر : (فتح الباري) لابن حجر (r/؟ ؛). }
\end{aligned}
$$

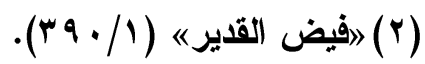

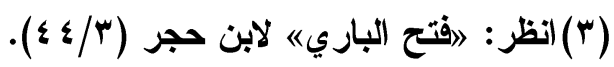

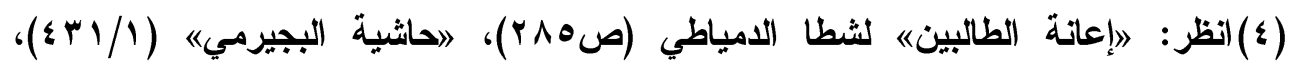

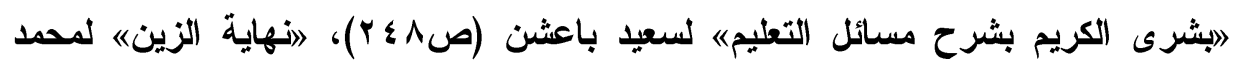

$$
\begin{aligned}
& \text { عر نووي الجاوى (ص 1 + 1). }
\end{aligned}
$$

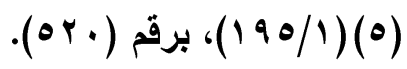

$$
\begin{aligned}
& .(1 r q / r)(7)
\end{aligned}
$$




$$
\text { ضجعة الفـــر : مفهومها - صفتها - محلها - حكمها }
$$

قال فيه الأهبي: 》اليس بشيع)(1). وله طريق آخر عن أبي المليح، عن عبدالله بن رباح الأتصاري، عن عائشة

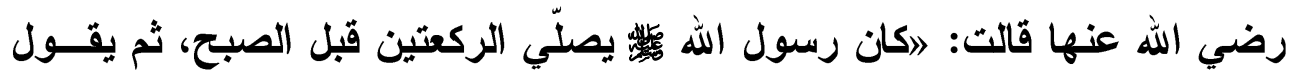

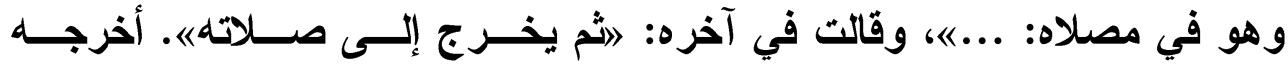

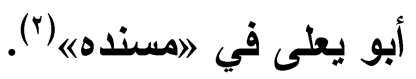

وأورد الفقيه الثشافعي شطا الآِّمياطي - عفا الله عنه - في حاثيتهة 》إعانـــة

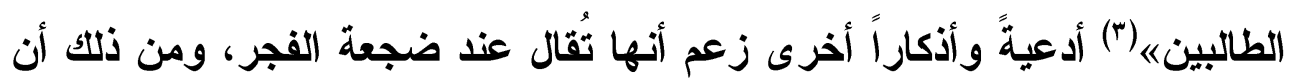
يقول: 》الموت الموت! اللهم كما حكمت عليَّ بالموت أن تكفينـي شــرَّ ســكرات الموته، ويسكت سكتة لطيفة يتذكر فيها أنه في القبر !! والظاهر أنه هذا من فعل المتصوفة؛ فإنه نقله من رسالة سمَّاها \الصدق والتحقيق لمسن أراد أن يسـير بسير أهل الطريق)؛ وعز اها لمن سمَّاه الثيخ أحمد الجُنيدي. وزعم عن كثير ممن سمَّاهم بالعارفين أن يقول: ليا حي يـــا قيـوم، لا إلـــهـ إلا أنتش؛ أربعين مرة!! وله أن يقول كذلك: لايا حي يا قيوم، يا بليع الســموات

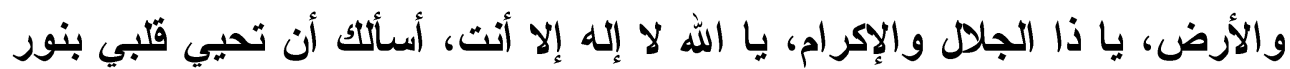
معرفتك، يا الله يا الله يا الله، يا أرحم الر احمين!!ه. وزعم أن بعسض الأثــياخ استحبَّ أن يُقال هذا الأكر بين سنة الصبح والفريضة! وعليه؛ فلا يثبت ذكر مخصوص لهذه الضجعة، والحمد لله ربِّ العالمين.

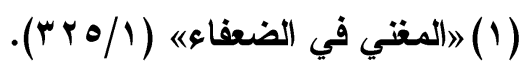

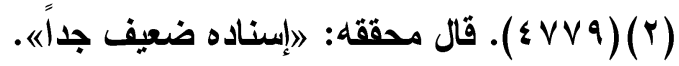
$\cdot($ ( $)(\varphi)(r)$ 


$$
\text { ضجعة الفـــر : مفهومها - صفتها - محلها - حكمها }
$$

\section{الامبمث الثاني \\ أقوال العلماء في ضجعة الفهر}

* وفيه مطلبان : 2 - 2

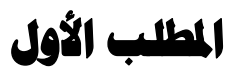 \\ مكاية أقوال أهد المام وأدلتهم}

من نافلة القول التنويه بأن العلماء - رحمهم الله تعالى - بين مُفْرط ومفرِّط

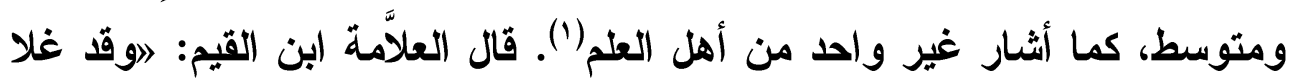

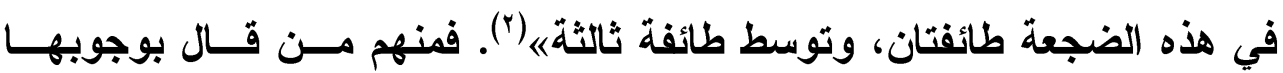

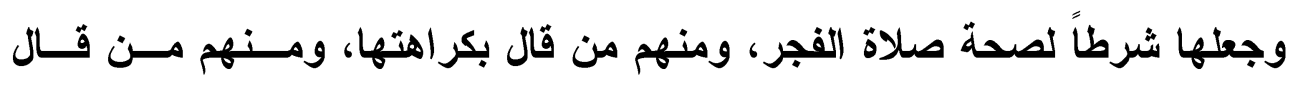

باستحبابها، ومنهم من قال بالتفصيل.

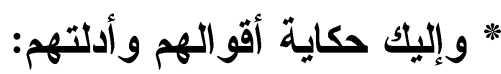
القول الأول: استحباب ضجعة الفجر.

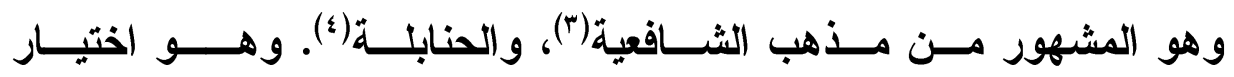

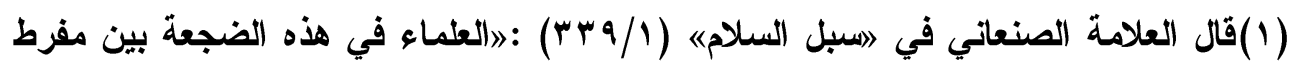
ومفرّط ومتوسطه.

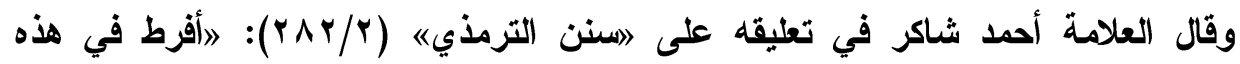

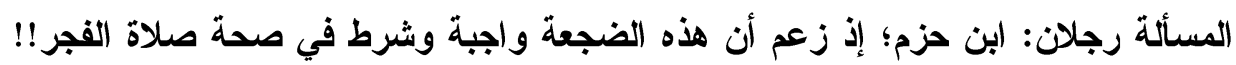

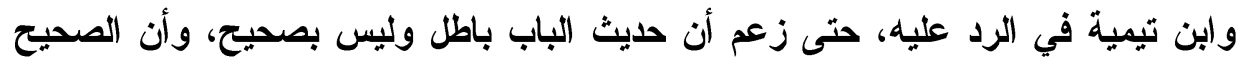
القعل لا الأمر بهاها.

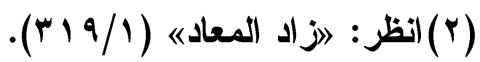

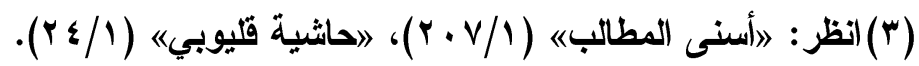

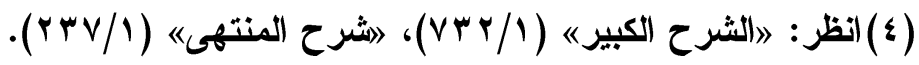




\section{ضجعة الفـــر : مفهومها - صفتها - محلها - حكمها}

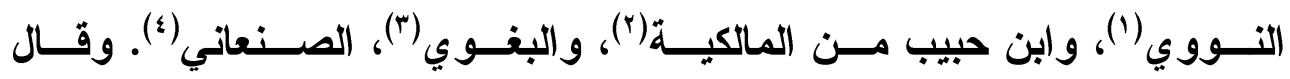

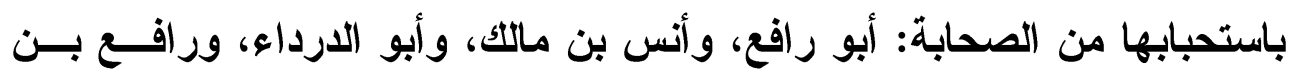

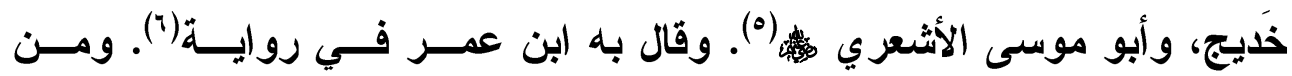
التابعين: الفقهاء السبعة؛ كلهم كانوا يضطجعون على أيمانهم بين ركعتي الفجـر

وصلاة الصبح (v)

\section{* واستدلوا على استمبابها بالقرآن، والسنة، والآثار:}

\section{أولاً: القرآن الكريم}

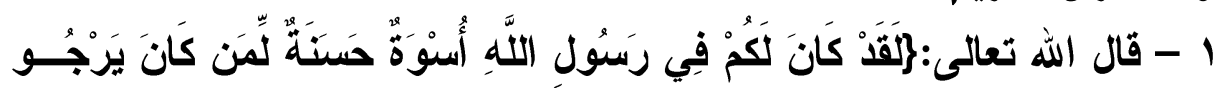

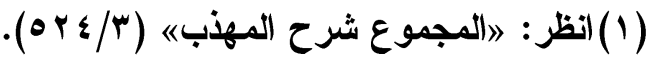

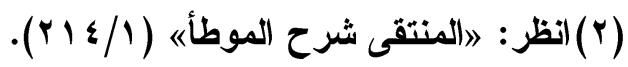

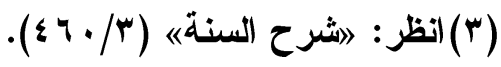

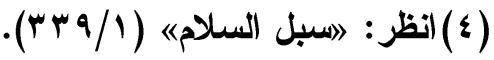

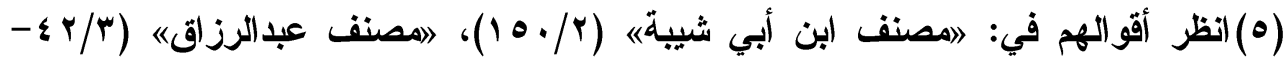

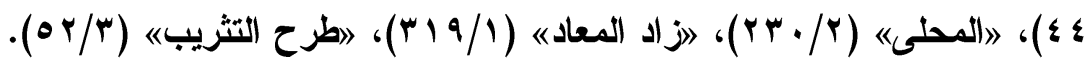

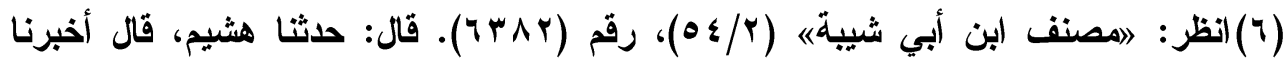

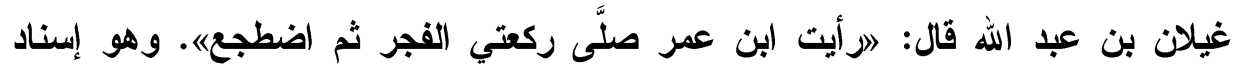

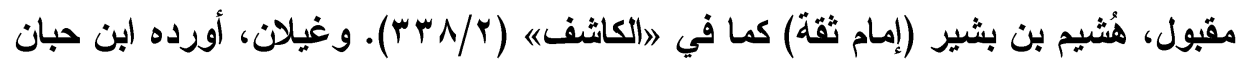

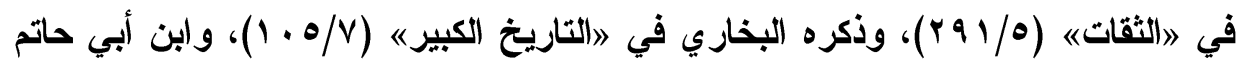

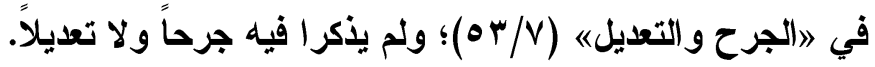

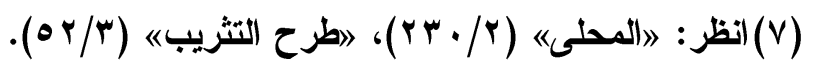

و الفقهاء السبعة - كما هو معروف - هم: سعيد بن المسيب، والقاسم بن محمد بن أبي

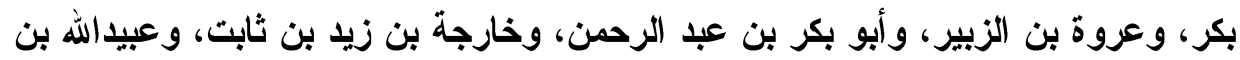

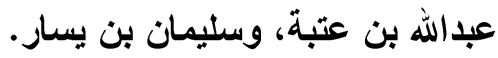




$$
\text { ضجعة الفـــر : مفهومها - صفتها - محلها - حكمها }
$$

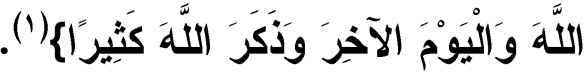

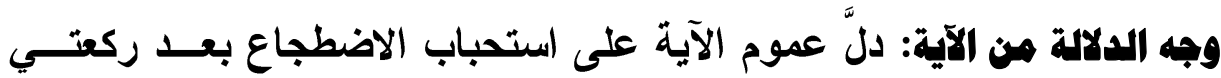

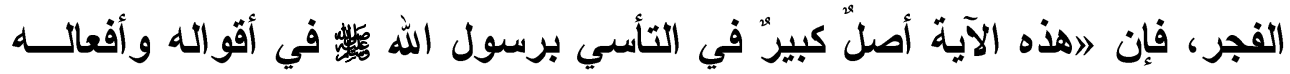
وأحواله/(r). و الضجعة داخلة في عموم التأسي؛ فكاتت مندوبة.

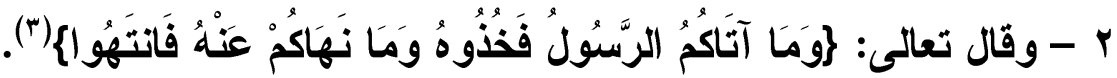

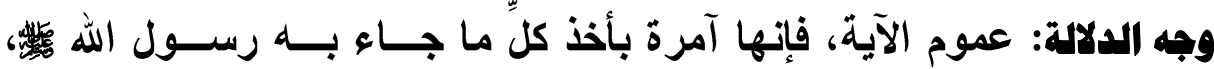
والاتتهاء عن كل ما نهى عنه عليه الصلاة والسلام، ومما جاء به ضجعة الفجر .

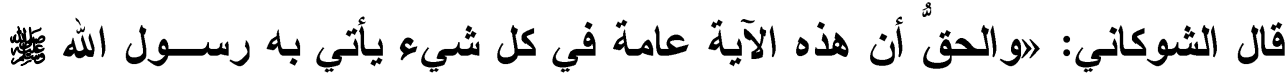

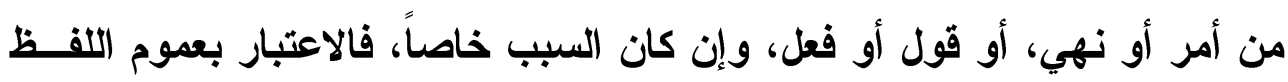

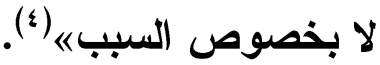
ثانيكا: السنْة النبوينة

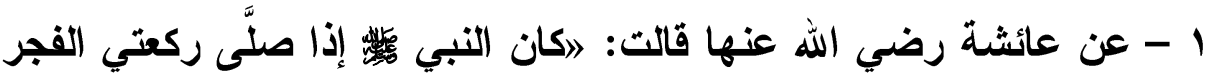
اضطبع على شقه الأيمنه (०).

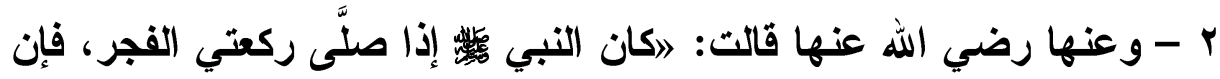

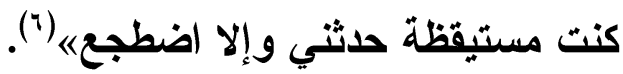

$$
\begin{aligned}
& \text { (1)سورة الأحزاب: آية آب. }
\end{aligned}
$$

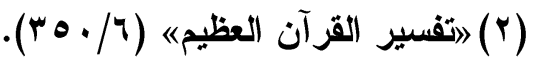

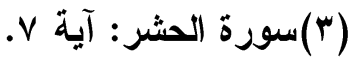

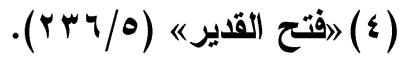

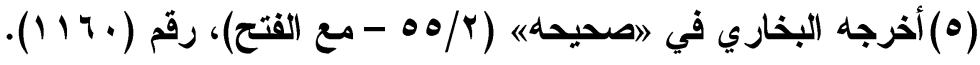

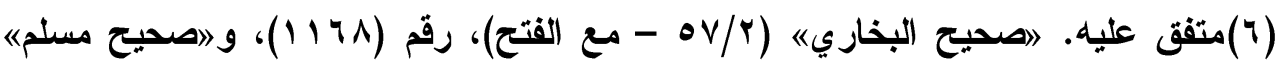

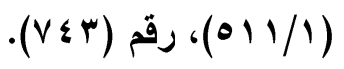


ضجعة الفــجر : مفهومها - صفتها - محلها - حكمها

وجه الدلالة منهمها: تصريح عائشة رضي الله عنها أن رســول الله

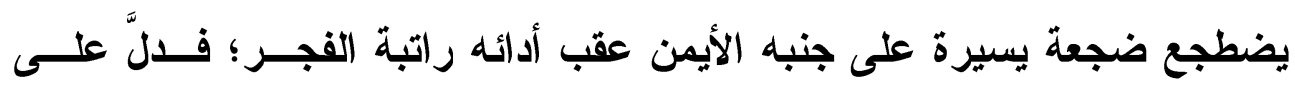

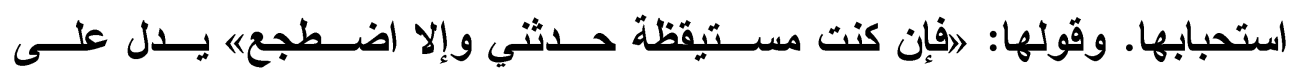
الاستحباب لا الوجوب.

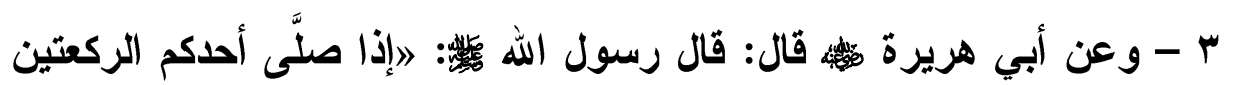

قبل صلاة الصنّبح فليضطبع على جنبه الأيمنه (1).

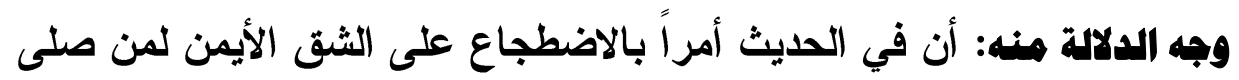
ركعتي الفجر قبل الصلاة، وهو أمر استحباب لديث عائشة المتقدم، فإنه صارف لهذا الحديث من الوجوب إلى الندب، لاوظاهره أنه كان لا يضطبع مع استيقاظها، فكان قرينة لصرف الأمر إلى الندبه(؟).

القول الثاني: وجوب الضجعة، وأنها شرط في صحة صلاة الفجر.

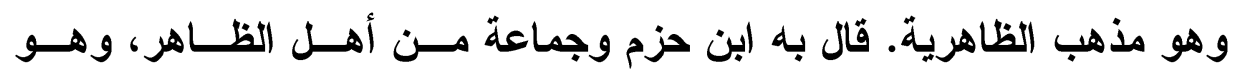

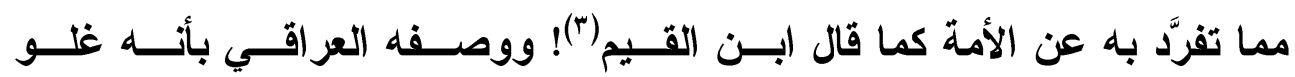

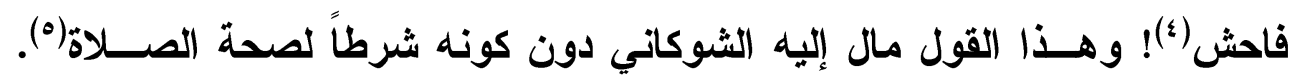

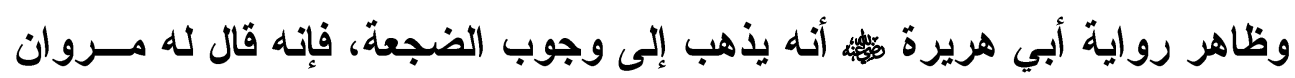

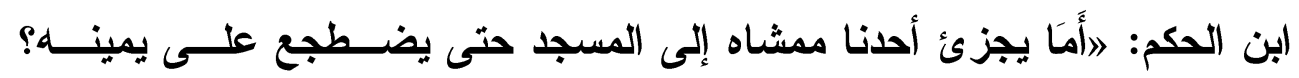

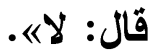

$$
\text { (1) (1) مقدَّم تخريجه. }
$$

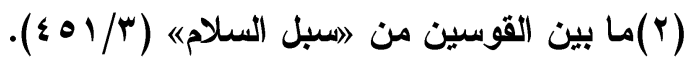

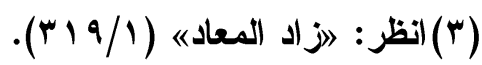

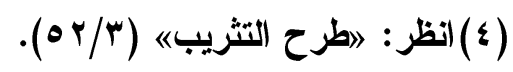

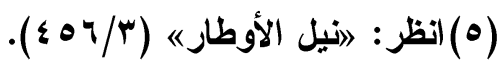




$$
\text { ضجعة الفـــر : مفهومها - صفتها - محلها - حكمها }
$$

قال ابن حزم: ״كل من ركع ركعتي الفجر لم تجزه صــلاة الصــبح إلا بـــأن يضطجع على شقه الأيمن بين سلامه من ركعتي الفجر وبـين تكبيـره لصــلاة

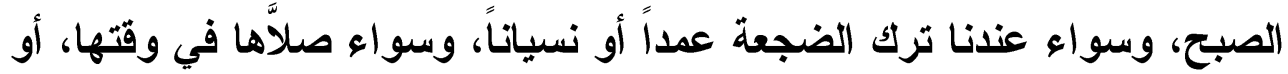
صلاَّها قاضياً لها من نسيان أو عمد نومه" (1).

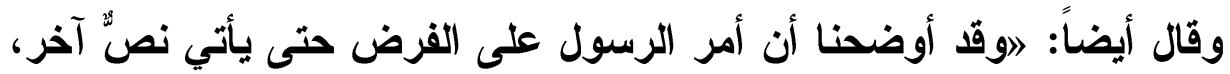

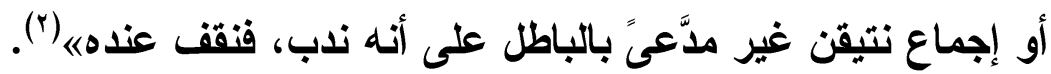

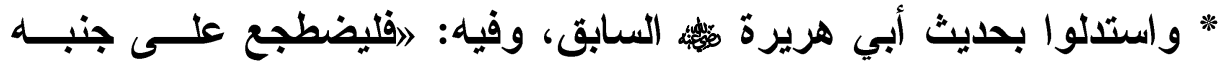

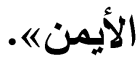

ووجه الدلالة منه: أن فيه تصريحاً بالوجوب لقوله: (فليضطبع)، وهو أمسر بالاضطجاع، والأصل في الأمر أنه للوجوب كما تقرَّر في الأصول ("). القول الثالث: كراهة ضجعة الفجر وعدم مشروعيتها. وهو المشهور من مذهب المالكية، وعندهم فيها روايتان: روايــة بالكراهـــة

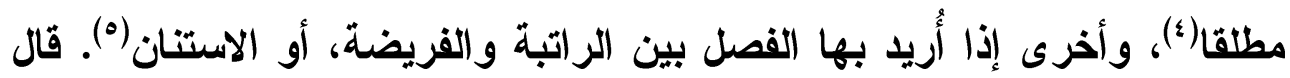

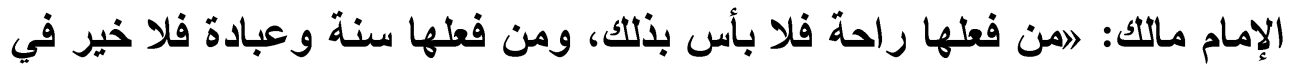

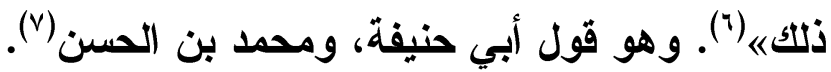

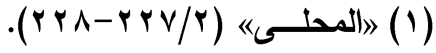

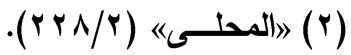

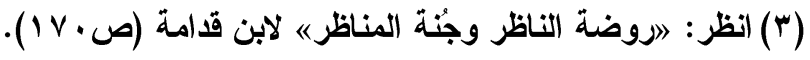

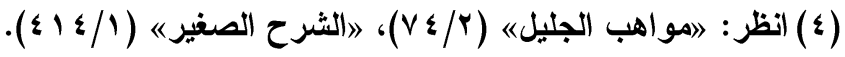

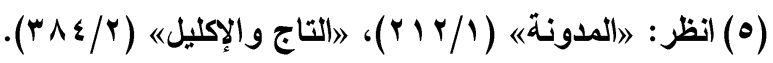

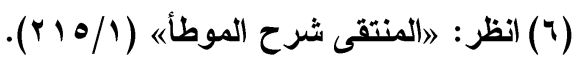

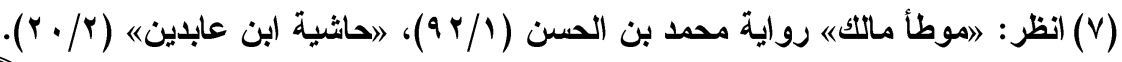




$$
\text { ضجعة الفـــر : مفهومها - صفتها - محلها - حكمها }
$$

وهو محكيٌ عن ابن مسعود، وابن عمر، وجابر بن زيل سعيد بن المسيب، وإبراهيم النخعي، والأسود بن يزيد، وسعيد بن جبير، والحسن

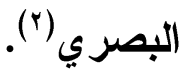

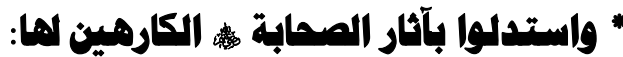

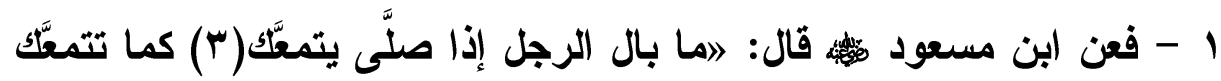

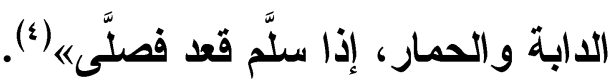

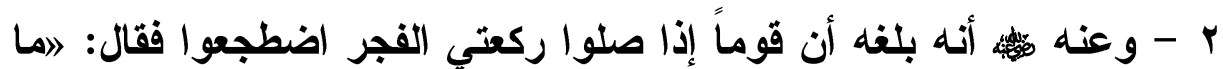

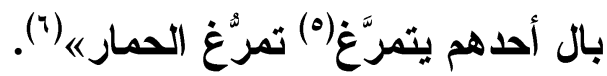

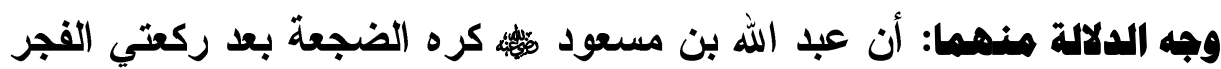

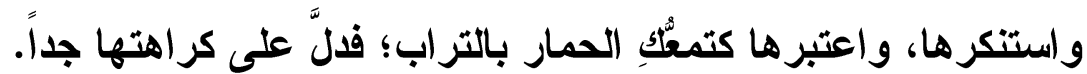

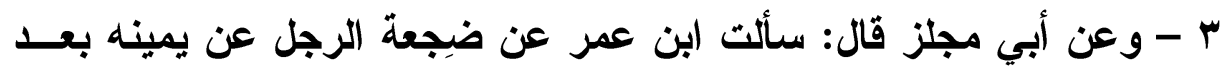

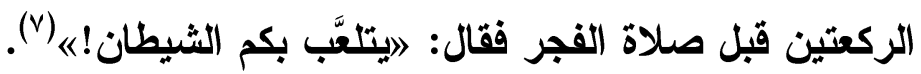

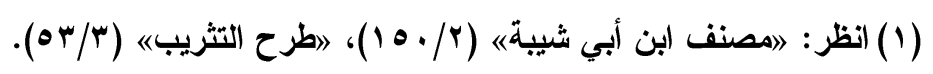

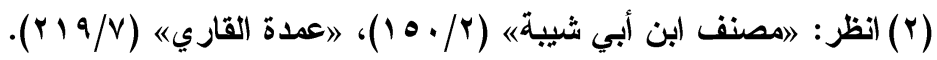

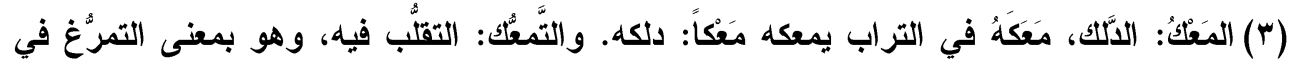

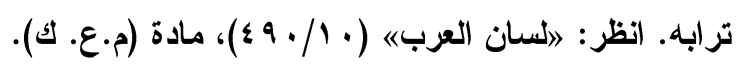

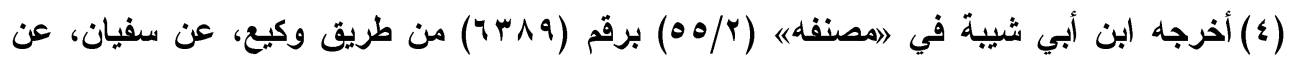

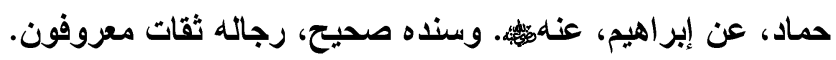

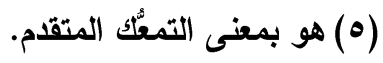

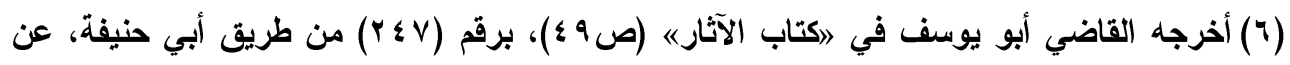

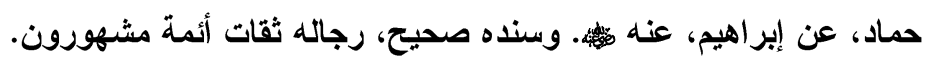

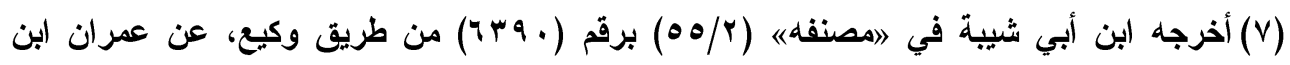

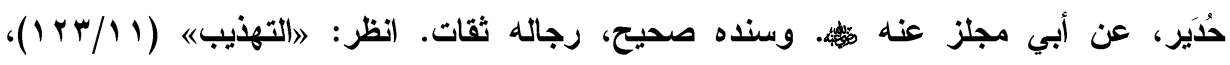

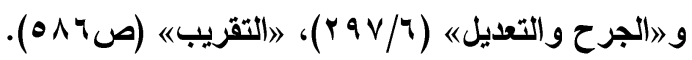




$$
\text { ضجعة الفـــر : مفهومها - صفتها - محلها - حكمها }
$$

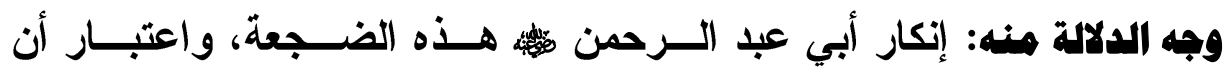
الثيطان - نعوذ بالله منه - يتلاعب بمن يضطجعها.

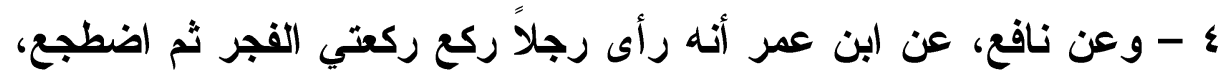
فقال ابن عمر: (ما شأنه؟!). فقال نافع: فقلت: يفصل بين صلاته. قال ابن عمر:

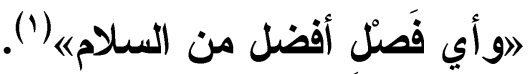
وجه الدلالة منه: استنكار ابن عمر رضي الله عنهما ضجعة الرجل بعد ركعتي

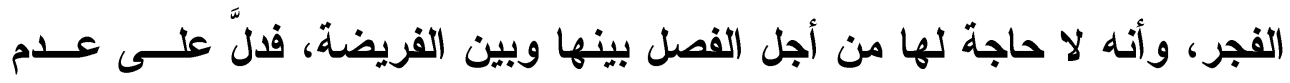

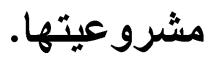

\section{ومن أدلتهم: أن هذه الضجعة ليس عليها عمل أهل المدينة(؟).}

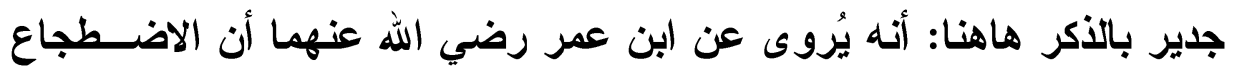

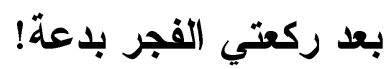
روى ذلك ابن أبي شيبة عن أبي الصديق الناجي قال: ارأى ابن عمر قومــاً

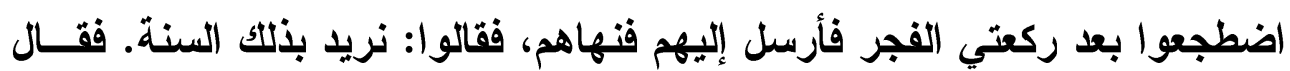

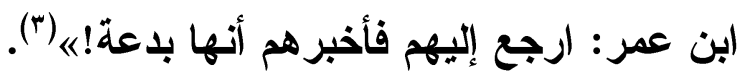

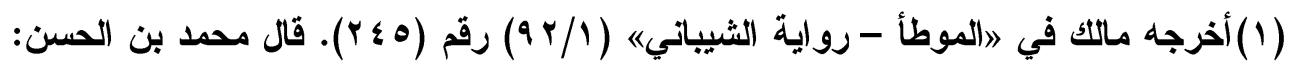
》اويقول ابن عمر نأخذ، وهو قول أبي حنيفة رحمه الله).

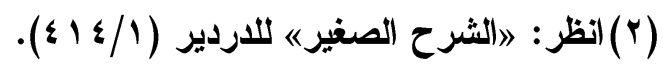

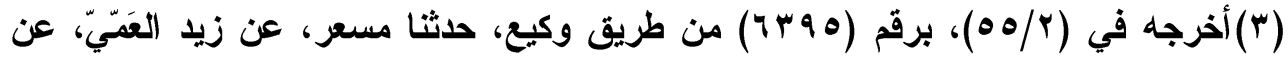

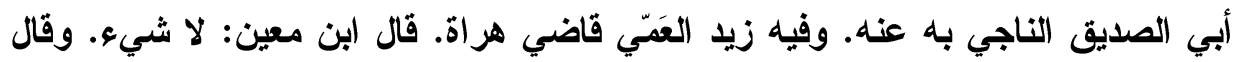
أبو زرعة: ليس بقوي، واهي الحديث، ضعيف. وقال النسائي: ضعيف. انظر: التهذيب الهيد

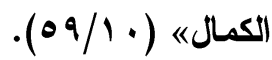




$$
\text { ضجعة الفـــر : مفهومها - صفتها - محلها - حكمها }
$$

وهذا الأثر على فرض صحته؛ فإنه محمول على كراهيتــهـ الاضــطجاعَ فــي المسجد، كما سيأتي.

القول الرابع: التفريق بين من يقوم الليل ومن لا يقومه، فمن يقوم تستحب له الضجعة لأجل الراحة ومن لا يقوم لا تشرع في حقه. واختار هذا القول القاضي ابن العربي المالكي، فقــال - رحمــهـ الله - : اولا

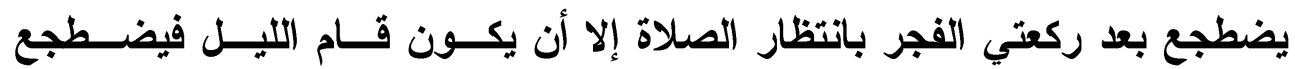

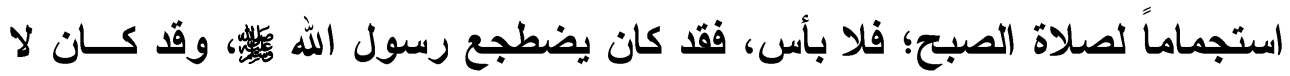

يضطجعب) (1) وهو رواية عن الإمام مالك كما تقدَّم قوله: 》امن فعلها راحة فلا بأس بــللك،

ومن فعلها سنة وعبادة فلا خير في ذلكه ().

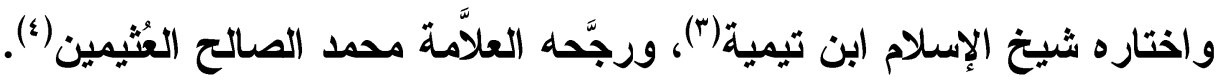

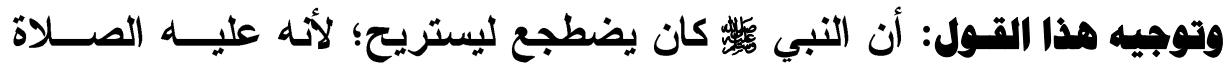

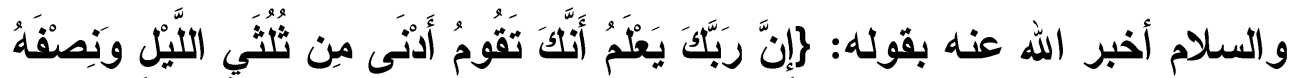

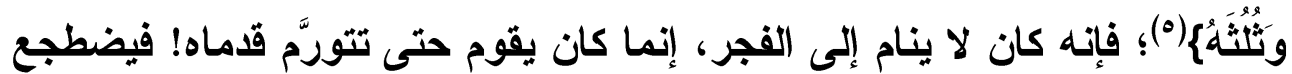
حتى يأتيه المؤذن يؤذنه بالصلاة، فيقوم ويصلي، ويكون هذا من أجل الراحة(؟)! القول الفامس: أن الضجعة ليست مقصودة لذاتها، وإنما المقصود الفصل بين

(1) (عارضة الأحوذي بشرح صحيح الترمذيه (Y/ع اب).

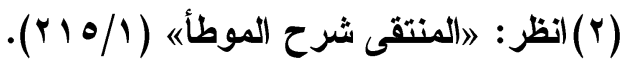

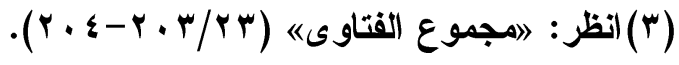

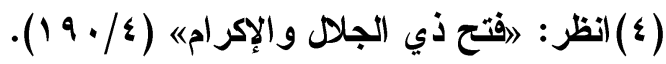

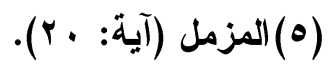

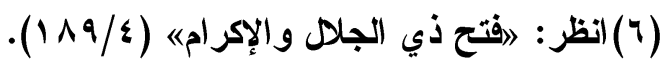




$$
\text { ضجعة الفـــر : مفهومها - صفتها - محلها - حكمها }
$$

ركتي الفجر والفريضة.

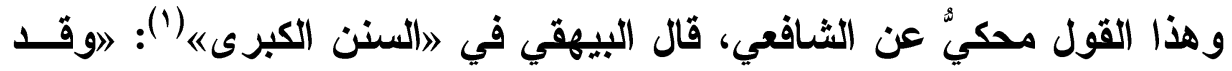

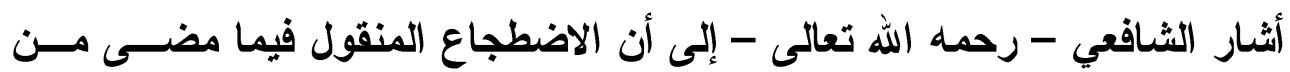

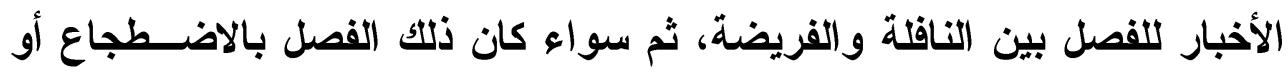

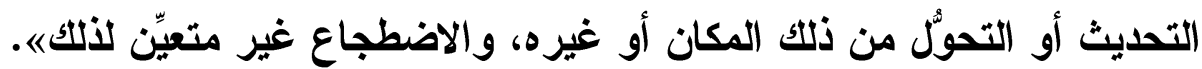

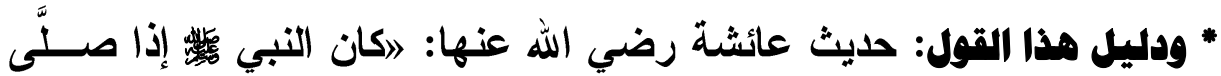

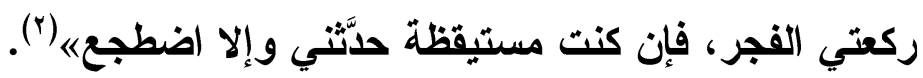

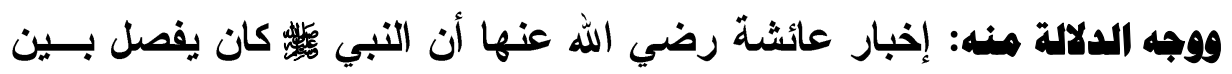

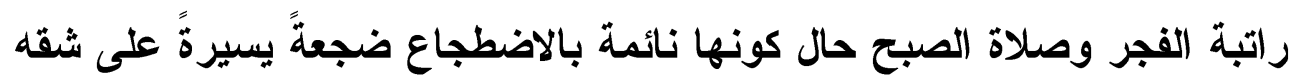

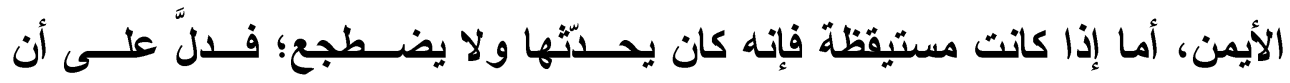
الاضطجاع من أجل الفصل ليس إلاًّ.

\section{الإلب الثاني

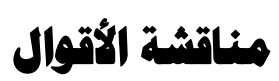

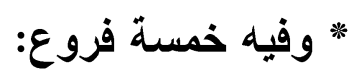

\section{الفرع الأول}

\section{مناقشة القاليلين باستحباب ضجعة الفهر}

\section{أولاً: نوقش استدلاهم بالقرآن الكريم هن وجهين:}

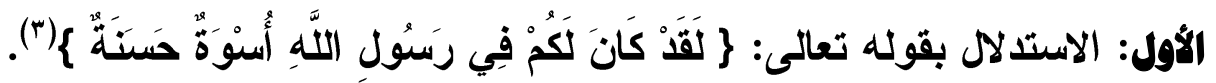

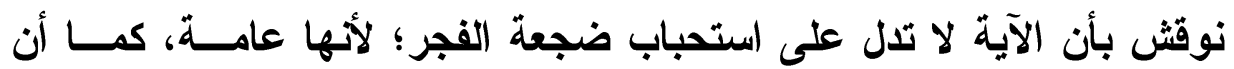




$$
\text { ضجعة الفـــر : مفهومها - صفتها - محلها - حكمها }
$$

الضجعة من أفعال النبي والاليل إذا تطرَّق إليه الاحتمال سقط به الاستدلال.

\section{وأبِيس عنه بثلاثة أمهر:}

أولها: أن أهل العلم أجمعوا على أن السنة أقوال وأفعال وتقريز، وقد ألزمــــ

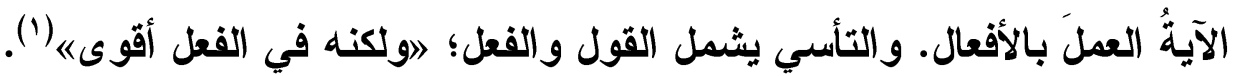

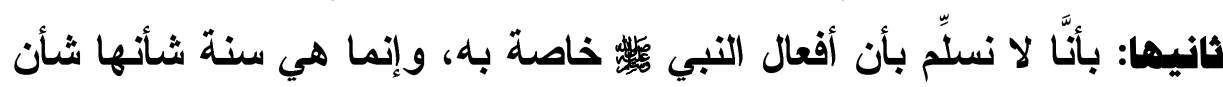

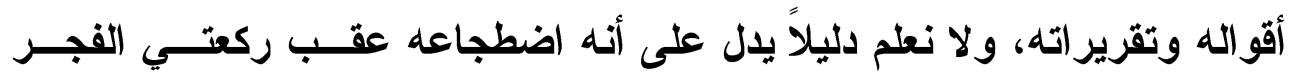

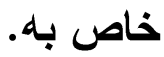
قال العلآَّمة عبد الرحمن السعدي - رحمه الله تعالى -: 》استثلَّ الأصــوليون

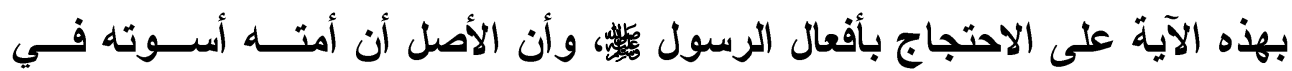

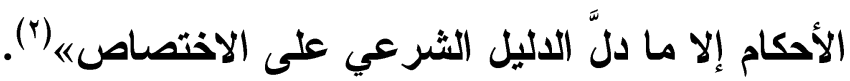

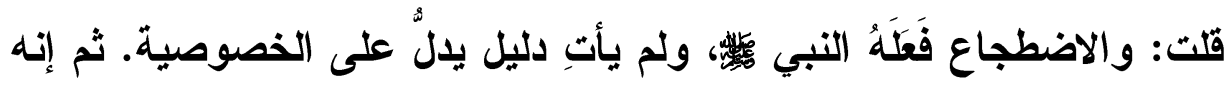

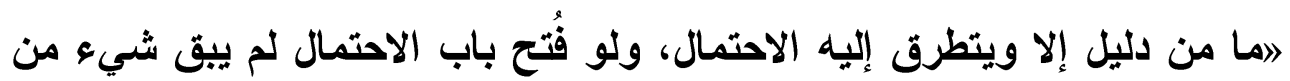
الأدلة إلا وسقط الاستدلال به بدعوى تطرق الاحتمال إليه!ه(ז).

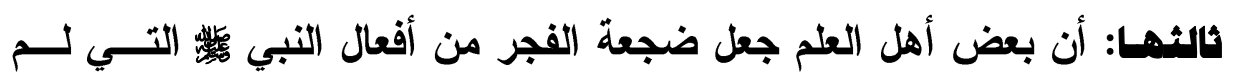

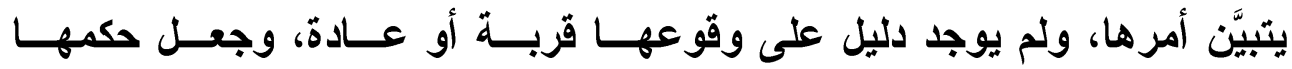
الاستحباب، فيُستحب للأمة اتباع النبي في فئه فيها، ويندب إلى ذلك، فيُحمل على أن

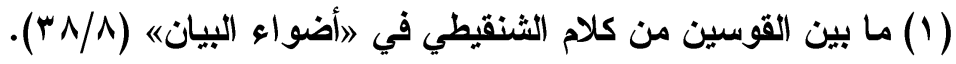

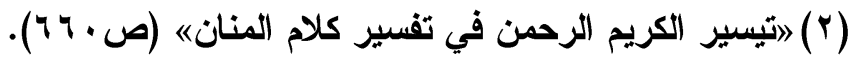

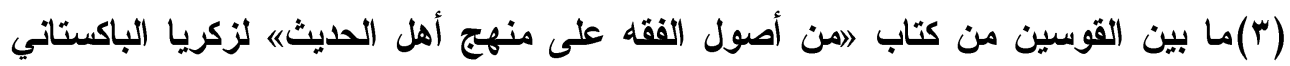




$$
\text { ضجعة الفـــر : مفهومها - صفتها - محلها - حكمها }
$$

فعله للضجعة أرجح من تركه، وهو الندب(1).

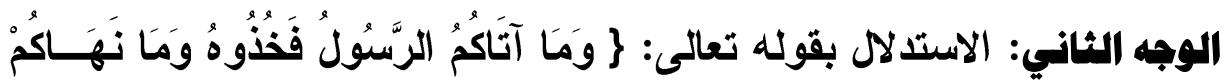

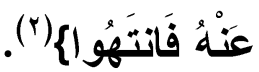

نوقش بأن الآية عامة، والاستدلال بها على استحباب ضجعة الفجر توستُّع، فلا تصلح للاحتجاج على ما أردتم.

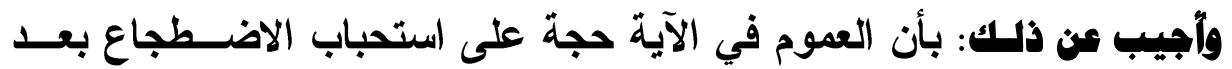

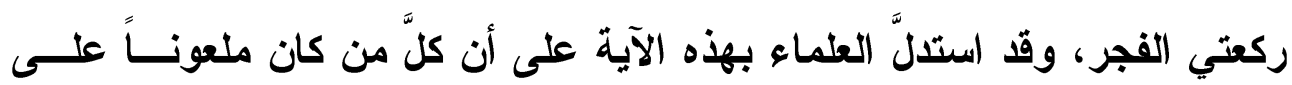
لسان النبي

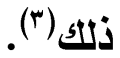

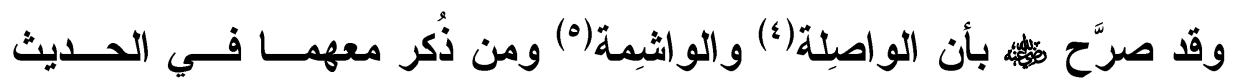

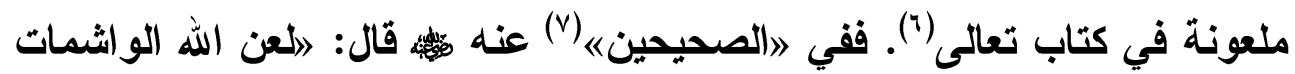

(1) (انظر : 》الجامع لمسائل أصول الفقه وتطبيقاتهاه لعبد الكريم النملة (ص ب ا I).

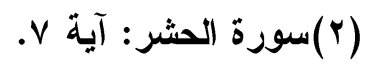

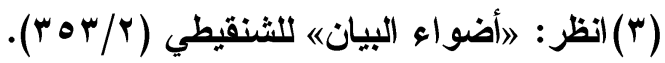
(ع)الواصِلة: التي تصل شعرها بثعر آخر زور. انظر: 》النهاية في غريب الحديثه

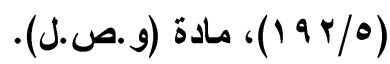

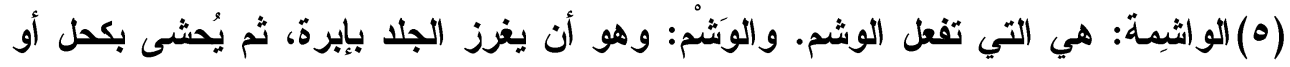

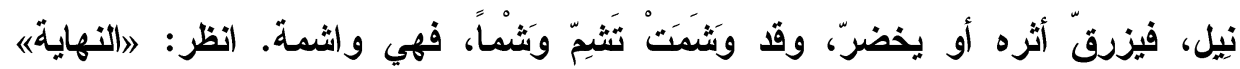

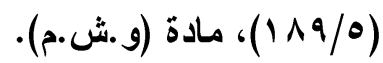

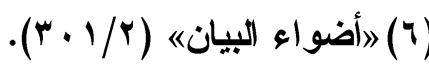

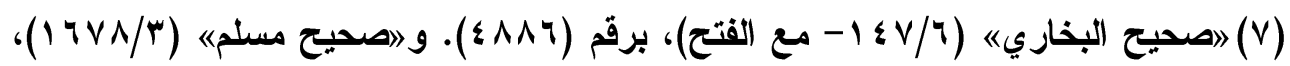

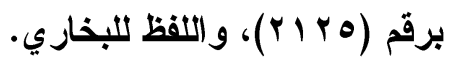


ضجعة الفــجر : مفهومها - صفتها - محلها - حكمها

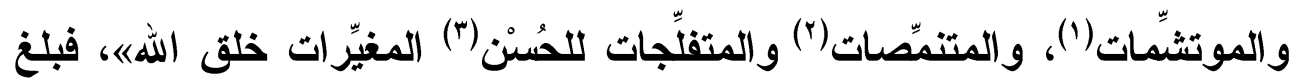

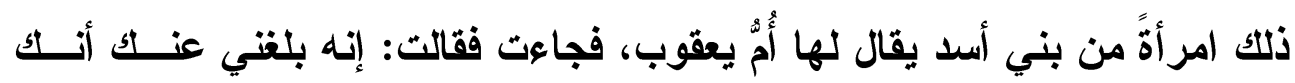

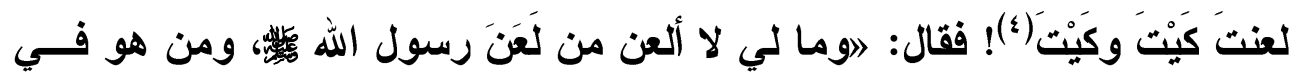
كتاب اللهی، فقالت: لقد قرأث ما بين اللوحين فما وجدت فيه ما تقول! قال: 》الئن

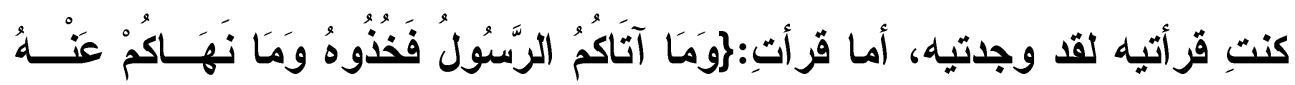

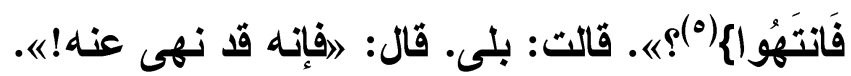

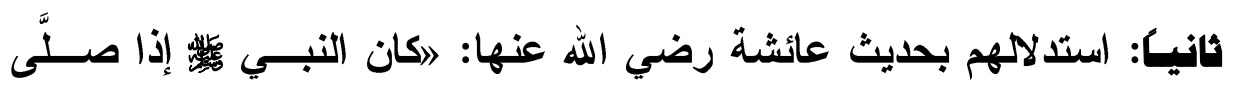

ركعتي الفجر اضطجع على شقه الأيمنه(؟). نوقش هذا الدليل: بأنه جاء في بعض رواياته أن الاضطجاع كان قبل ركعتي

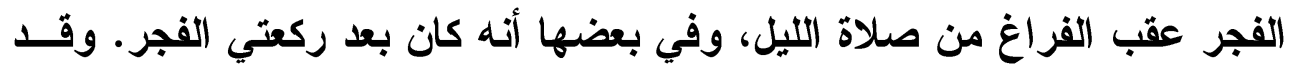
أشار القاضي عياض - رحمه الله تعالى - أن رواية الاضطجاع بعد ركعتي الفجر مرجوحة، فنقدِّم رواية الاضطجاع قبلهما (V).

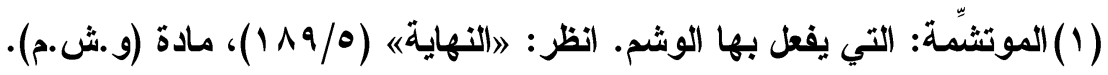

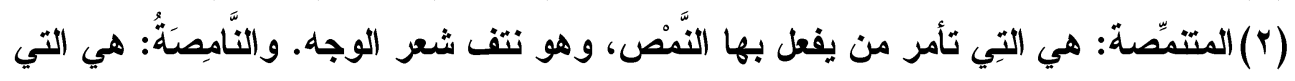

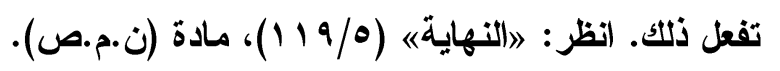

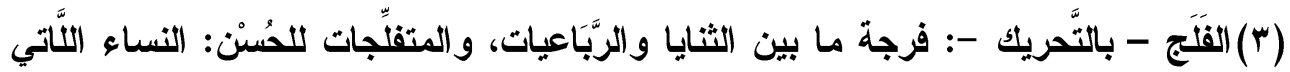

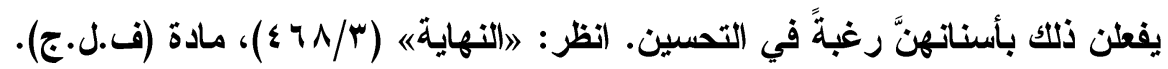

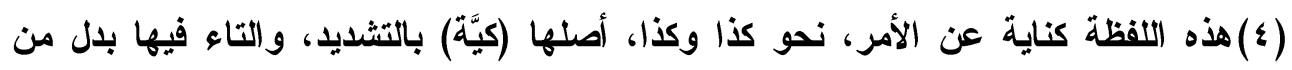

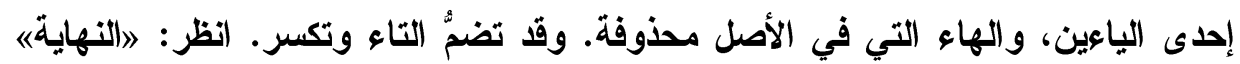

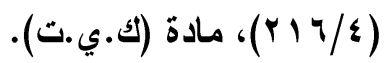

$$
\begin{aligned}
& \text { (0)سورة الحشر: آية V. } \\
& \text { (ך) (ךقَّم تخريجه. }
\end{aligned}
$$

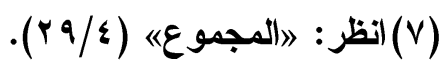




$$
\text { ضجعة الفـــر : مفهومها - صفتها - محلها - حكمها }
$$

والجواب عنه: أنـا لا نسلّم بترّجيح رواية الاضطجاع بعد صــلاة الليـلـل وقبــل

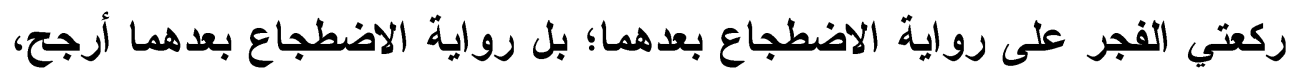

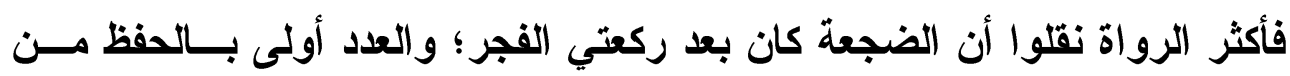
الواحد (1).

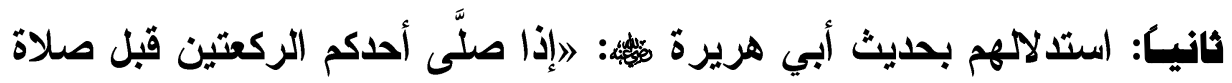

$$
\begin{aligned}
& \text { الصبح فليضطبع على جنبه الأيمنه(؟). } \\
& \text { نوقش هذا الدليل من أربعة وجوه: }
\end{aligned}
$$

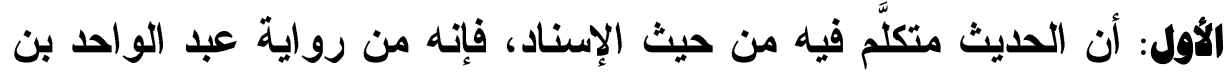

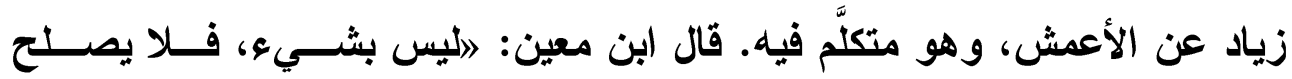

لكلاحتجاجه|" (").

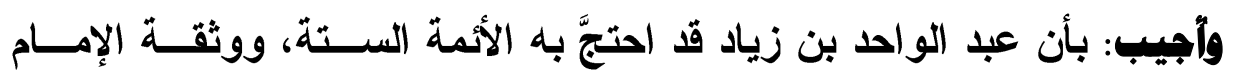

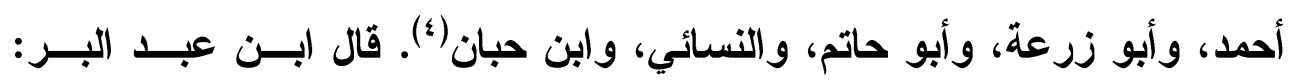

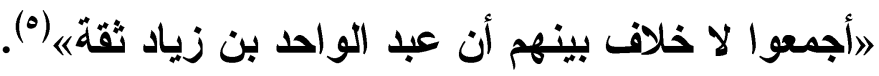

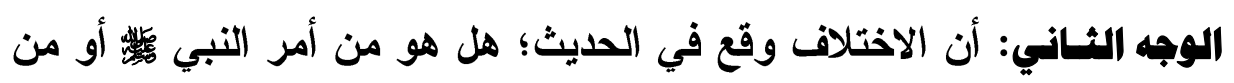
فعله؟ وكونه من فعل النبي السي هو المحفوظ.

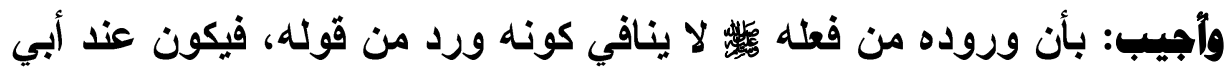
هريرة

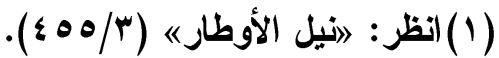

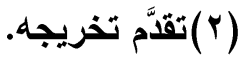

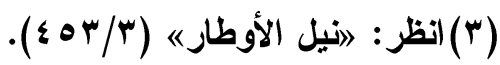

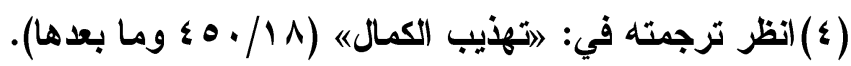

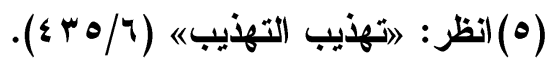




$$
\text { ضجعة الفـــر : مفهومها - صفتها - محلها - حكمها }
$$

والسلام؛ على أن الكلَّ يفيد ثبوت أصل المشروعية، فيردٌّ نفي النافين(').

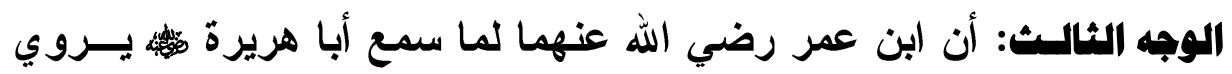

حيث الأمر بالضجعة قال: 》أكثر أبو هريزة على نفسه!ی)(r).

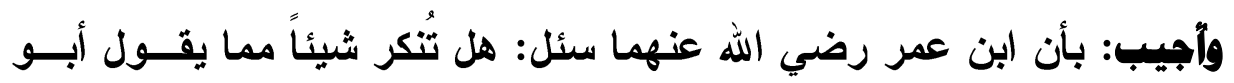

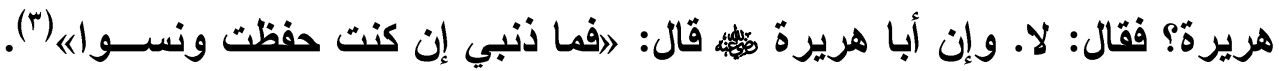

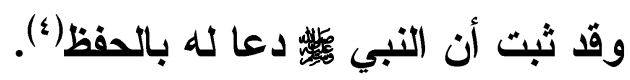
الوجه الرابـع: أن أحاديث الضجعة ليس فيها الأمر بها، إنما فيها فعله عليـــه

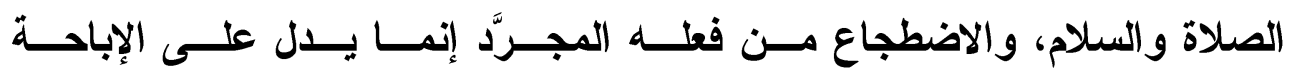

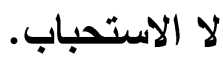

\section{وأجيب عنه من جمتين:}

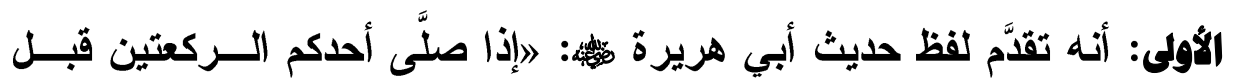
صلاة الصبّح فليضطبع على جنبه الأيمنه.

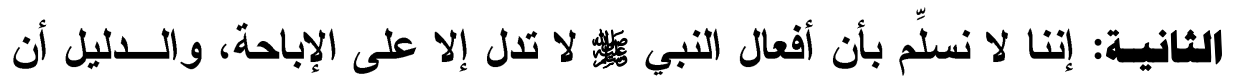

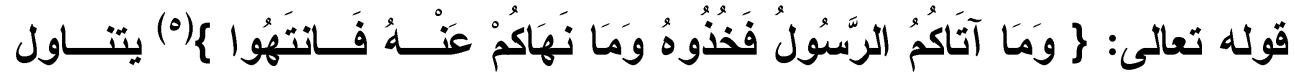

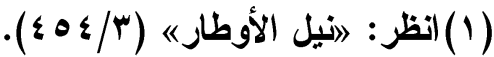

$$
\begin{aligned}
& \text { (Y) (Y) (Yَّم تخريجه. }
\end{aligned}
$$

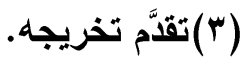

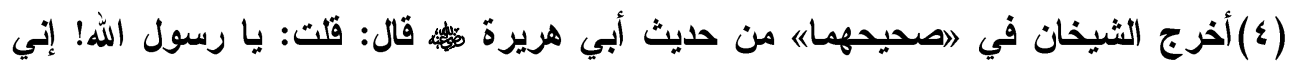

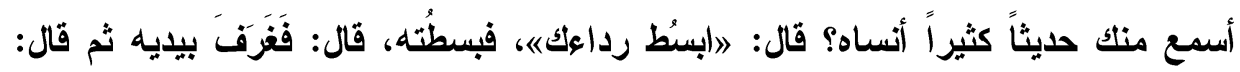

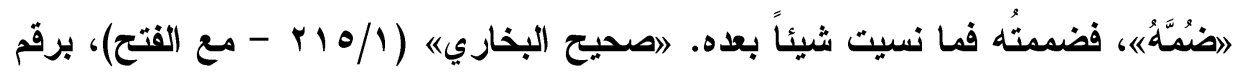

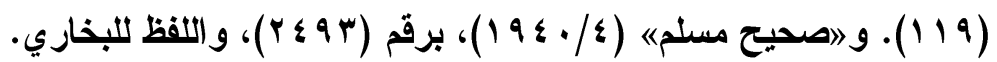

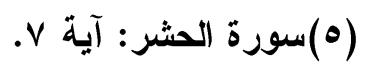




$$
\text { ضجعة الفـــر : مفهومها - صفتها - محلها - حكمها }
$$

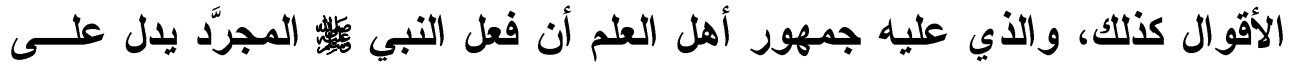
الندب؛ وهذا على فرض أنه ليس في أحاديث الضجعة إلا الفعل، مــع أن القــول

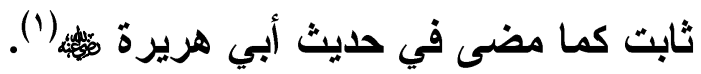
الفرع الثاني

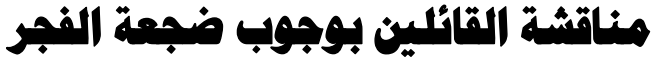

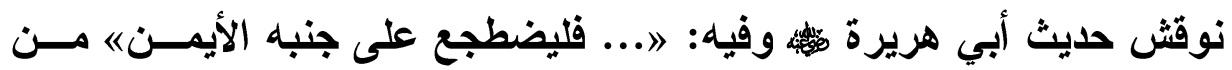

وجهين:

الأول: بما قاله ابن العربي - رحمه الله تعالّى -: >ابلغني عن قوم لا معرفــة عندهم أنهم قالوا بوجوبها، وليس له وجه؛ لأن النبي

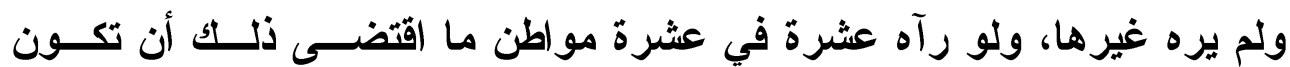

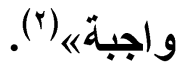

الوجه الثـاني: أن الأمر بالوجوب في قوله 》 فليضطبع «، مصــروف إلـى

الاستحباب بما ورد من عدم مداومته على فعل الضجعة؛ قاله الصنعاني (r).

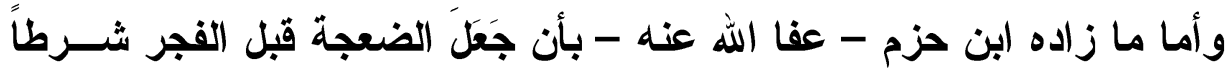

لصحة صلاة الصبح؛ وهذا من غرائبه وعجائبه! فهو مردود من وجهين أيضاً: الأول: أن القول بأن من تعمَّد ترك الضجعة أو نسيها لا تصـــحُّ منــهـ صــلاة

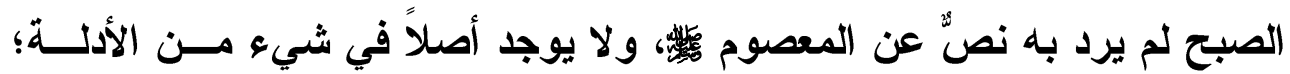

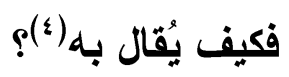

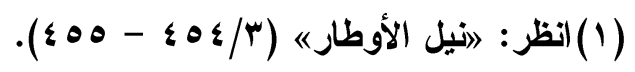

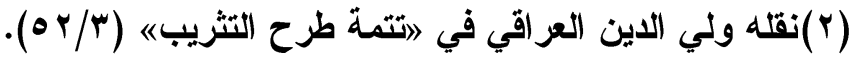

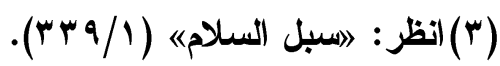

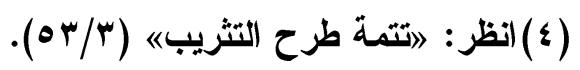




$$
\text { ضجعة الفـــر : مفهومها - صفتها - محلها - حكمها }
$$

الوجه الثـاني: أن هذا القول يستلزم منه بطلان أعمال صالحة كثيرة، بحيــث

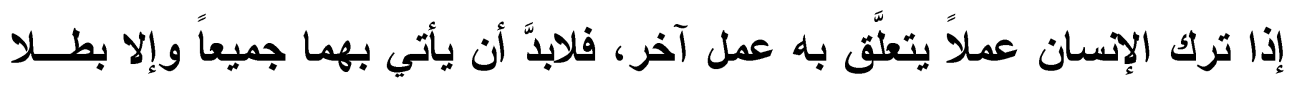
جميعا! وهذا لم يقل به أحد.

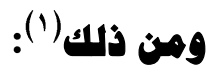

* لو ترك إنسان فريضة الظهر حتى دخل وقت العصر فصلاًّها، فيستلزم ذلتك

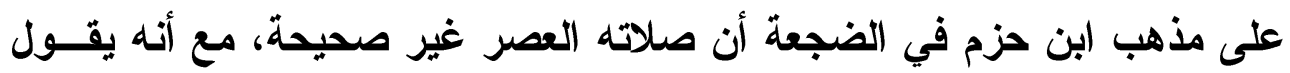

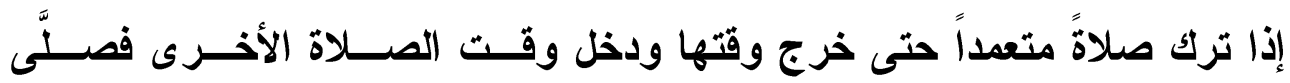

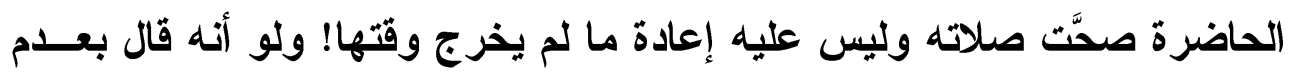

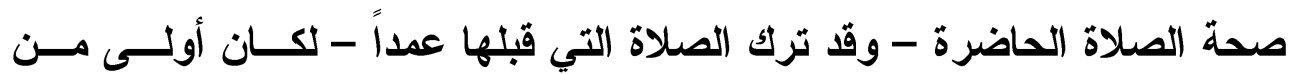
ترتيب الصلاة على اضطجاع ليس من جنس الصلاة.

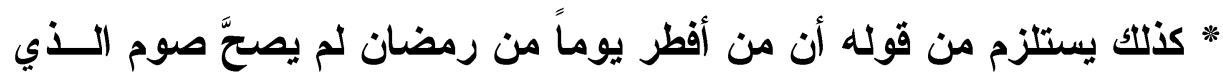

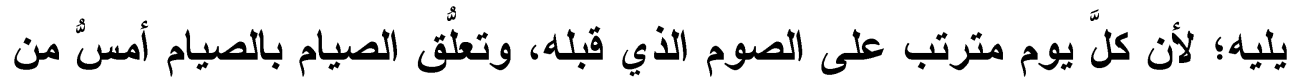

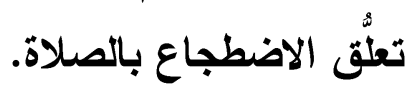

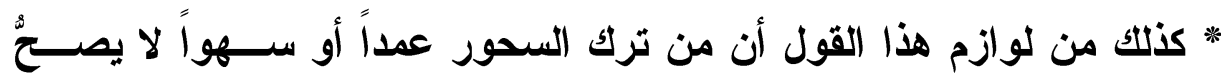

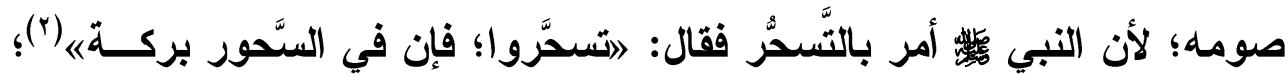

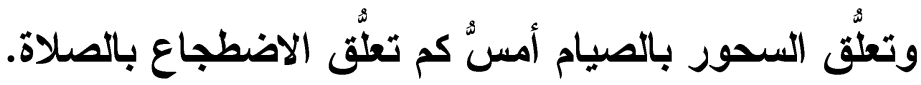

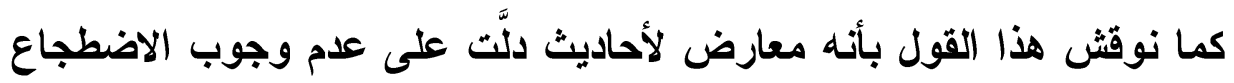

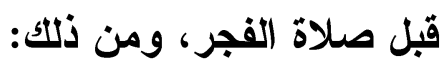

(1)جميع الأمثلة والردود أوردها الحافظ العر اقي رحمه الله. انظر: (اتتمة طرح التثريب) لابنه

$$
\begin{aligned}
& \text { ولي الدين (r/ rه و و ه). } \\
& \text { (r) آمتفق عليه. }
\end{aligned}
$$

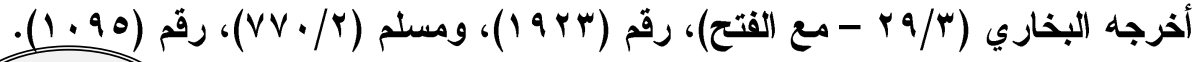




$$
\text { ضجعة الفـــر : مفهومها - صفتها - محلها - حكمها }
$$

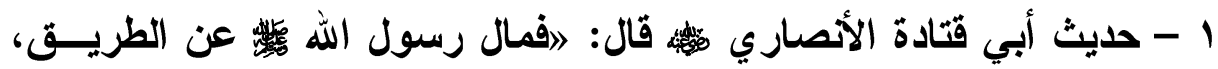
فوضع رأسه، ثم قال: 》احفظوا علينا صلاتنا《، فكان أول من استيقظ رســول الله  إذا ارتفعت الشمس نزل، ثم دعا بمِيضَأة(1) كاتت معي فيها شيع من ماءو، قـــال:

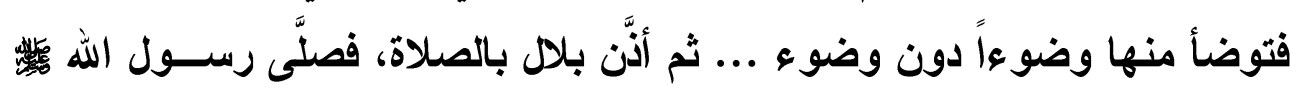
ركعتين، ثم صلَّى الغداةه) (r).

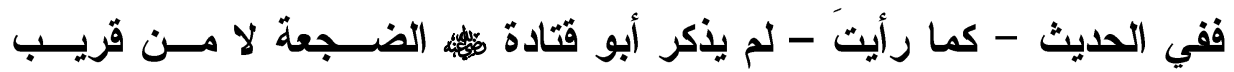
ولا من بعيد، وإنما ذكر وضوء النبي عليه الصلاة والســلام، وأذان بــلال، ثـم صلاته وأجاب عنه ابن حزم بأن الراوي سكت ههنا كما سكت عن الوضوء، وعمــا لابدَّ منه من ذكر التكبير للإحرام، والسلام، وغير ذلك، ويكون هذا الخبر قبل أن يأمر عليه الصلاة والسلام بالضجعة(ّ). قلت: وهذا تكلّف من أبي محمد - عفا الله عنه - ـ. r - ومنها حديث ابن عباس رضي الله عنهما في 》الصــحيحينه(أ) أيضــاً،

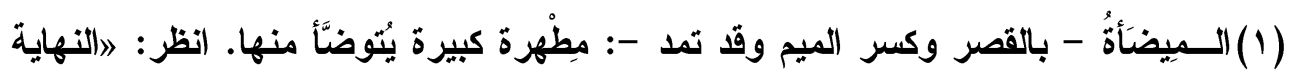

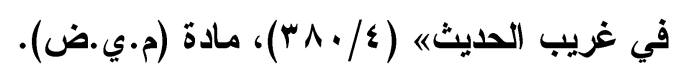
(Y) (Y) متقق عليه.

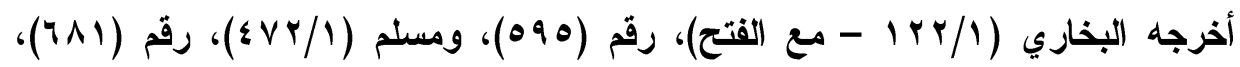
و اللفظ له.

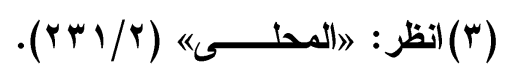

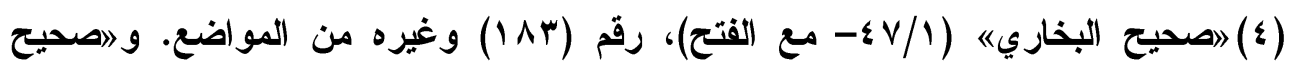

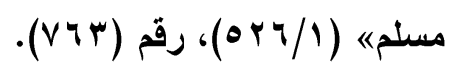




$$
\text { ضجعة الفـــر : مفهومها - صفتها - محلها - حكمها }
$$

فإنه وصف صلاة النبي وفيه: 》... فقام فصلَّى ركعتين خفيفتين ثم خرج فصلَّى الصنّبح).

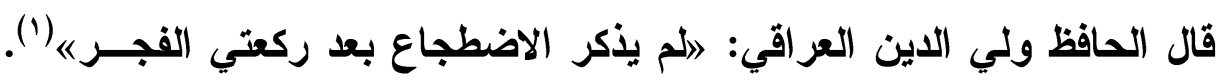
وهو كما قال.

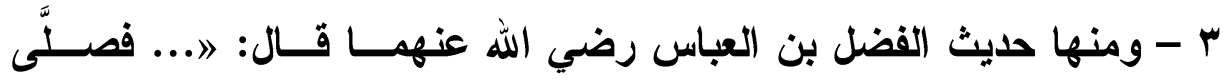

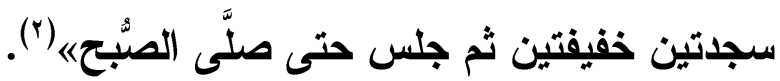
قال الحافظ ولمي الاين: الم يذكر فيه الاضطجاع رأساً، لا بعد ركعتي الفجــر،

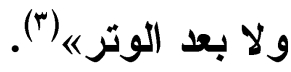

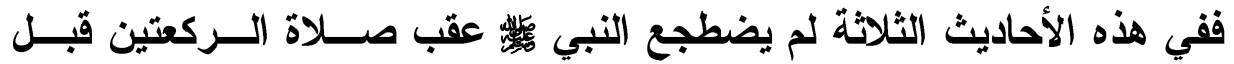
الفجر، ولو كاتت الضجعة واجبة لما تركها عليه الصلاة والسلام بحال.

\section{الفرع الثمالث}

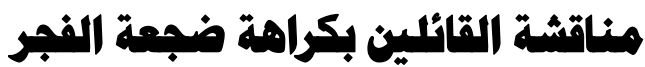

نوقشت الآثار التي استدلَّ بها أصحاب هذا القول على كراهة الاضطجاع بعـــ

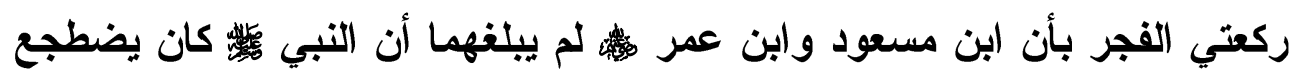
تلكك الضجعة، ولو بلغهم ذلك لم يقولا بالكر اهة.

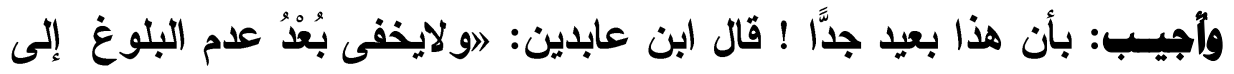

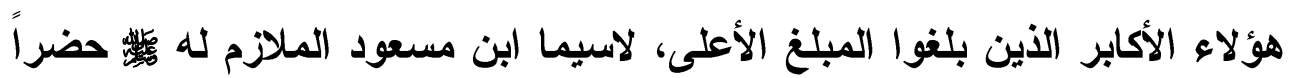

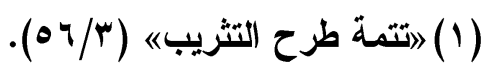

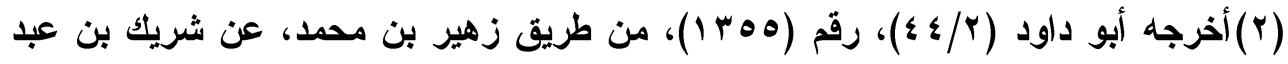

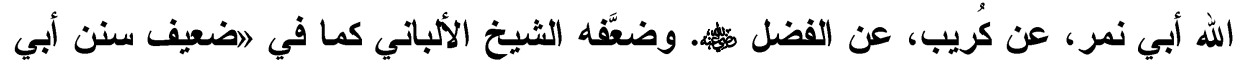

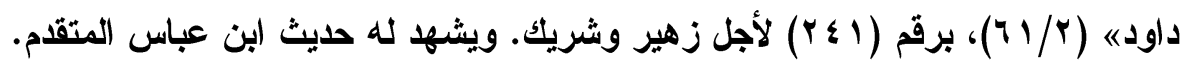

$$
\text { (ץ) (") }
$$


ضجعة الفــجر : مفهومها - صفتها - محلها - حكمها

وسفراً، وابن عمر المتفحِّ عن أحواله والصواب - والله أعلم - حمل إنكار هم على أمرين:

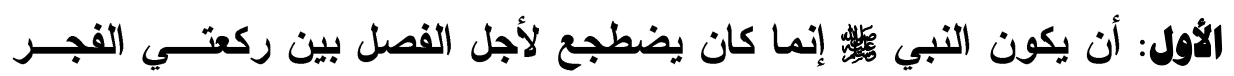
و الفريضة.

الثاني: أن يكون النبي * أما أثر ابن عمر رضي الله عنهما وقوله: (ارجع إلــيهم فــأخبرهم أنهـــا بلدعةه؛ فيُجاب عنه بأنه لا يصلح للاحتجاج لأمرين:

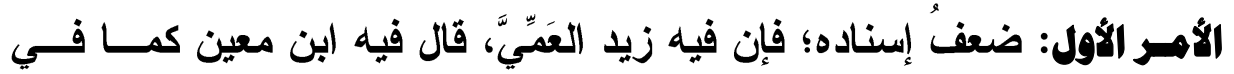

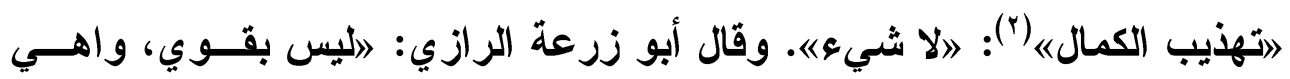
الحديث، ضعيف).

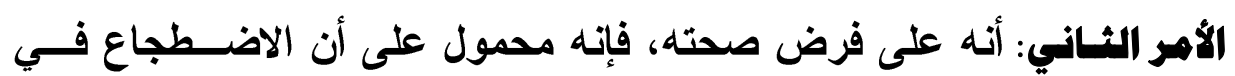

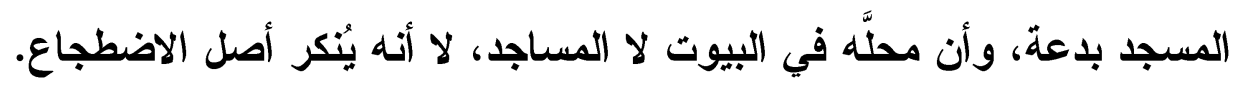

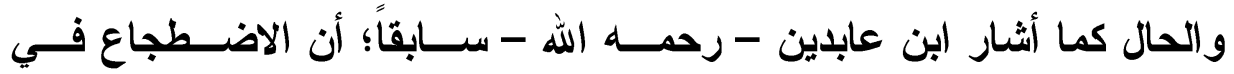

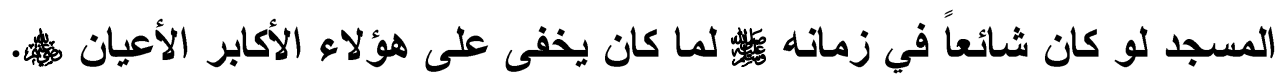
وأخيراً؛ نوقش دليلهم بأن الضجعة ليس عليها عمل أهل المدينة بأنه مردودُ؛

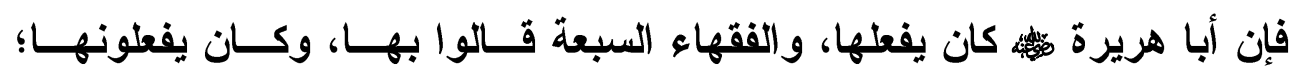

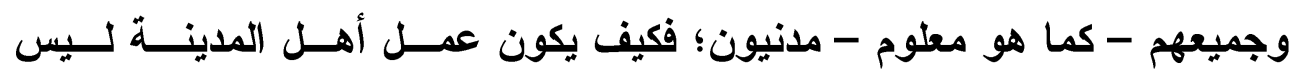
عليها!

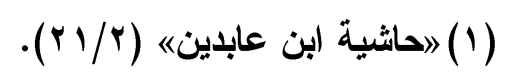




$$
\text { ضجعة الفـــر : مفهومها - صفتها - محلها - حكمها }
$$

\section{الفرع الرابع}

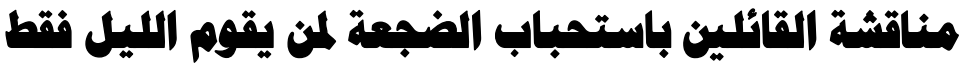

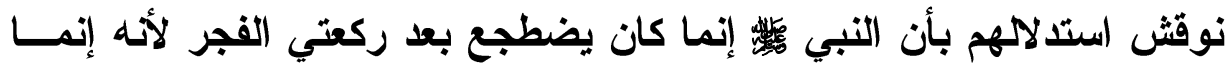
كان يقوم الليل، فكان يضطبع ليستريح؛ بأنتا لا نسلِّم لكم بذلك! فنحن مأمورون باتباع الرسول كئدة في أفعاله ليحصل لنا التأسي به عليه الصلاة والسلام، في نحو

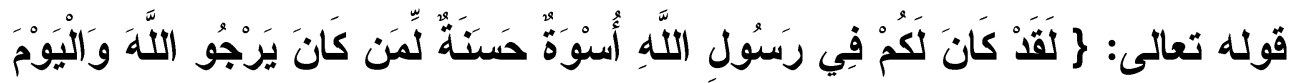
الآخرِ \{(')، وهل الأي يقوم أول الليل مثلاً، أو من لا يقوم الليل يُحرم من التأسي

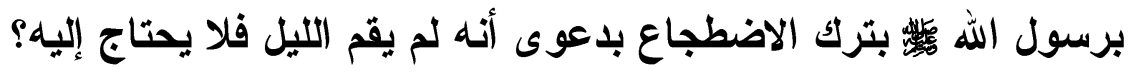
ولذا؛ فإن الاضطجاع مستحب لمن قام الليل وتهجَّد، ومن كان مستريحاً كمن قام أول الليل أو لم يقم. والله تعالى أعلم.

\section{الفرع الغامس}

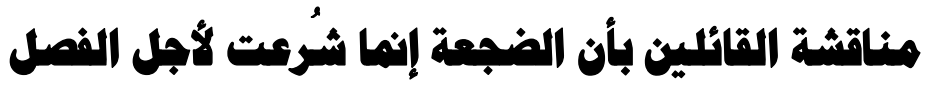

بين ركعتي الفجر والفريضة. نوقش حديث عائشة رضـــي الله عنهـــا الـــي احتجُوا به على أن الضجعة ليست مقصودة لذاتها، و إنما المقصود الفصل؛ بـأن

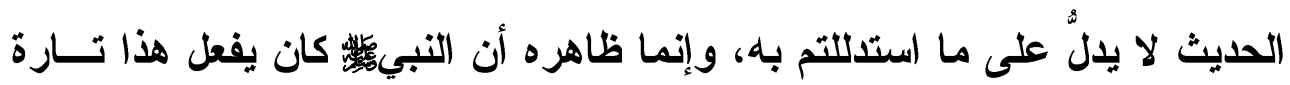
وهذا تارة، فمرة يتحدث مع عائشة رضي الله عنها إذا كان مســتيقظة، ومسرة

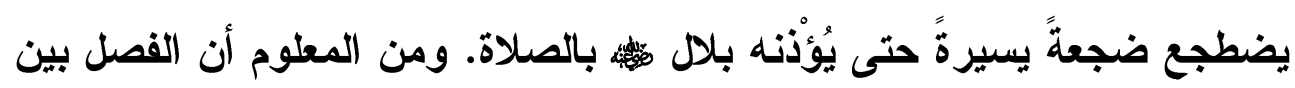
ركعتي الفجر وصلاة الصبّح يمكن أن يكون بأثياء غير الضجعة، فيمكن أن يكون

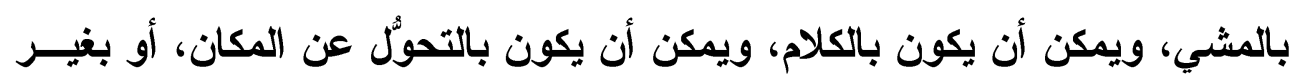

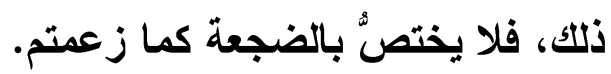

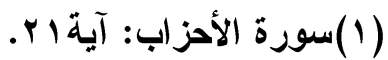




$$
\text { ضجعة الفـــر : مفهومها - صفتها - محلها - حكمها }
$$

\section{الإhب الثالث

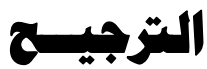

بعد دراسة أقوال أهل العلم في ضجعة الفجر، ومناقشة أدلة قول كـلِّ قــول

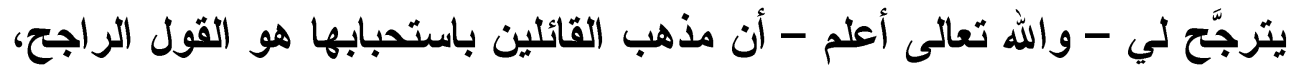
ومرجِّحات هذا القول الأمور الآتية:

أولاً: قوة أدلتهم وسلامتها من الفول الاهور الآبة: المعارضة.

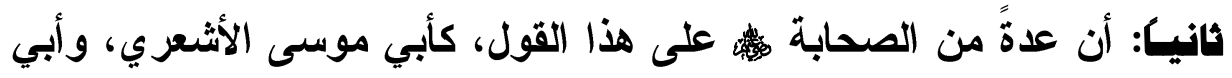

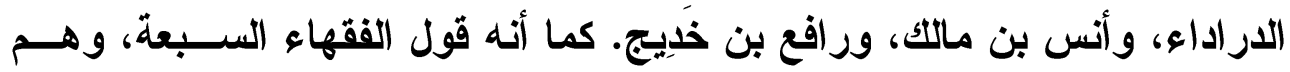
فقهاء المدينة من التابعين رحمهم الله تعالى.

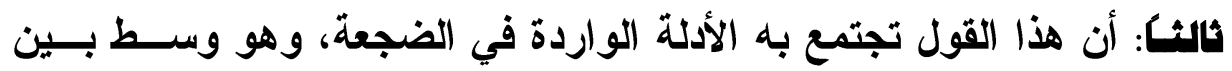

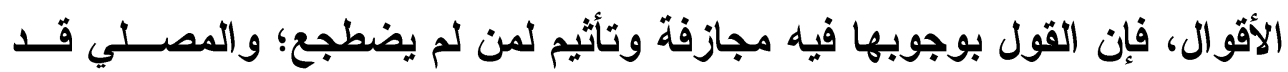

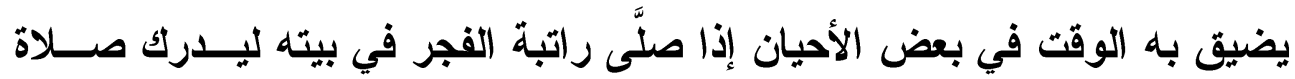

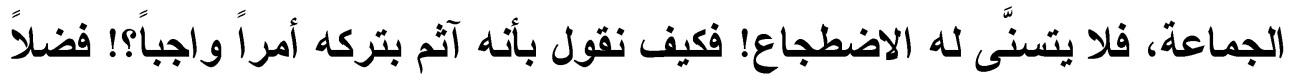

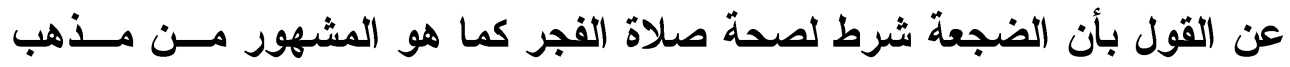

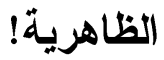

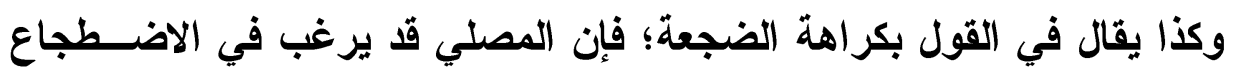

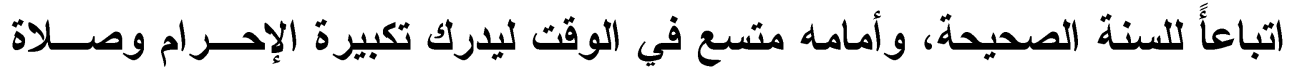

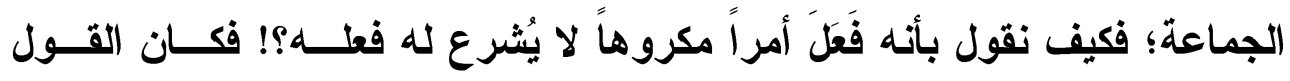
باستحباب الضجعة وسطاً بين الأقو ال؛ والحمد الله ربِّ العالمين. 


$$
\text { ضجعة الفـــر : مفهومها - صفتها - محلها - حكمها }
$$

\section{خماتمــة}

في نهاية بحثنا (ضجعة الفجر)، أودُّ تسجيل أبرز النتائج التي توصلت إليها، وقد تلخَّصت في الآتي: 1 - تبيَّن أن الناس في ضجعة الفجر - أعني العلماء - طرفان وواسطة، ما بين

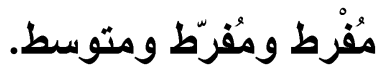

r - ضجعة الفجر ضجعة لطيفة تكون بين راتبة الفجر وصلاة الصُّح. r - أعدل الأقو ال في الضجعة القول باستحبابها لصحة الأحاديث وسلامتها مـن المعارضة، وهو وسط بين الأقو ال في المسألة. وأضعفها القول بوجوبها لإبها.

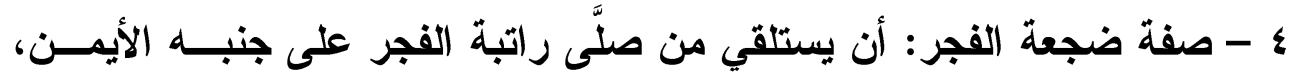
تثبه هيئته تلك الهيئة التي يكون عليها الإنسان في القبر.

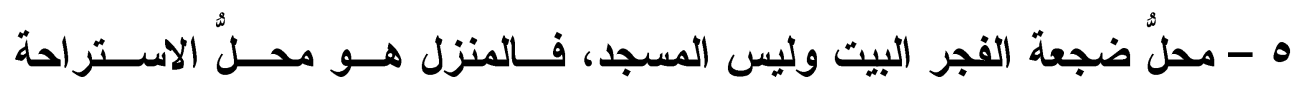
والاسترخاء وليس بيوت الله تعالى. ولى ولئ. צ - لضجعة الفجر حِكَّ معلومة، منها أن يتـــكر ضــــعة القبــر، والاســتراحة والاستجمام لمن قام الليل، والفصل بين ركعتي الفجر وصلاة الصنّح. V - ليس لضجعة الفجر ذكرّ مخصوصن، والأحاديث الواردة في هـــا الثـــأن لا يثبت منها شيء يُعتمد عليها. ^ - يجب على المضطجع ضجعة الفجر أن يكون حذراً من إغواء الثيطان، بحيث

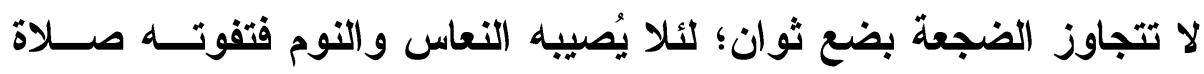

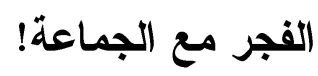




$$
\text { ضجعة الفــر : مفهومها - صفتها - محلها - حكمها }
$$

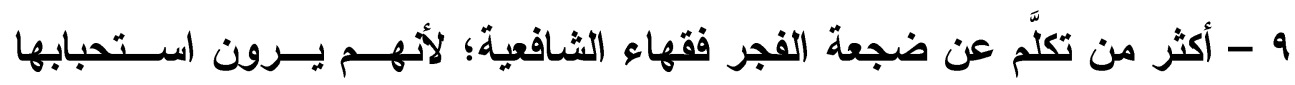

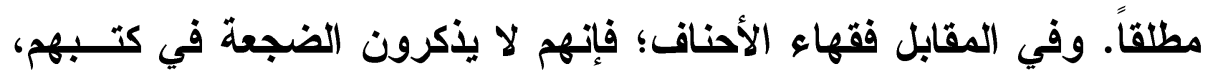
ولا يشيرون إليها إليها كما نبَّه عليه ابن عابدين ('). 


$$
\text { ضجعة الفـــر : مفهومها - صفتها - محلها - حكمها }
$$

\section{هراجع البمث}

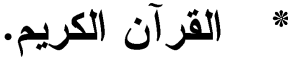

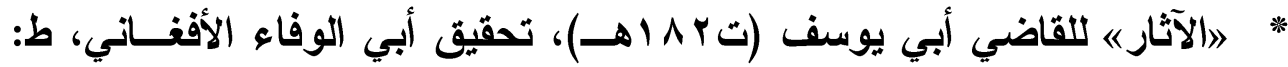

$$
\text { (باون)، دار الكتب العلمية، بيروث - لبنان. }
$$

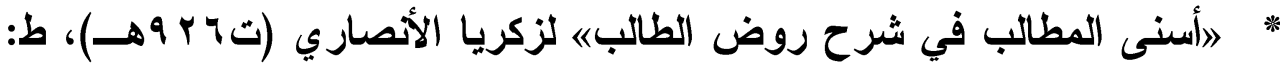

(باون)، دار الكتاب الإسلامي، بيروث (بدون تاريخ).

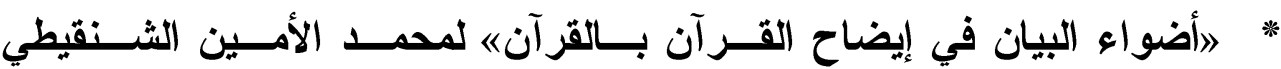

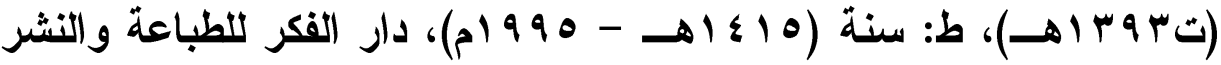

$$
\text { والتوزيع، بيروث - لبنان. }
$$

* * *إعانة الطالبين على حل ألفاظ فتح المعينه لأبي بكر بن محمد شطا (ت بعد

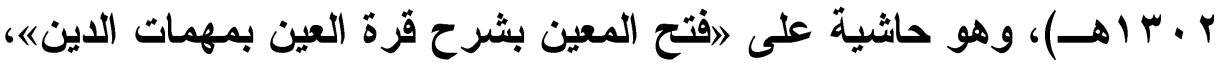

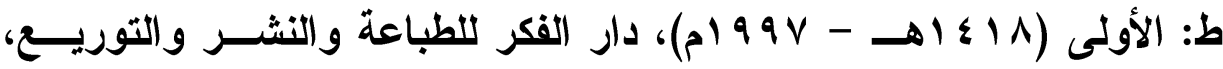

$$
\text { بيزوت - لبنان. }
$$

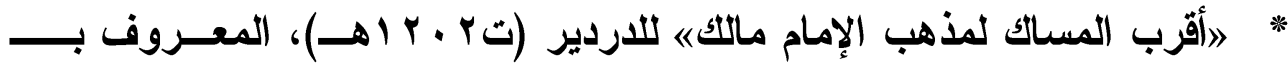

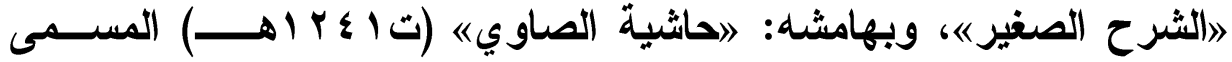

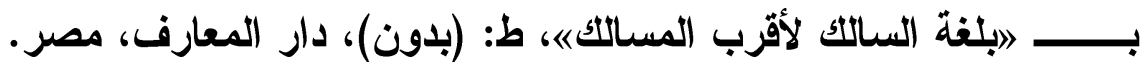

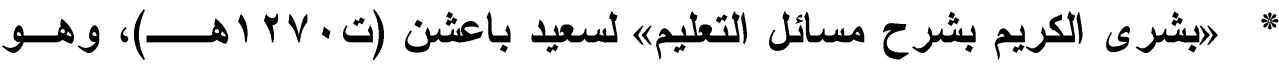

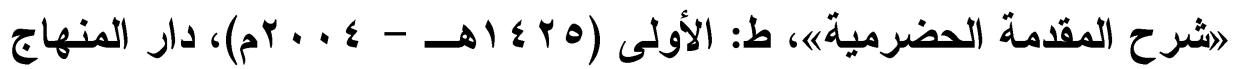
للاششر والتوزيع، جدة.

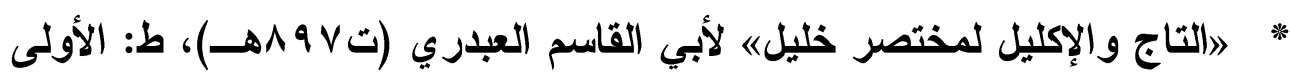

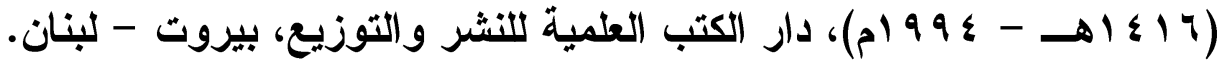




$$
\text { ضجعة الفـــر : مفهومها - صفتها - محلها - حكمها }
$$

》 التاريخ الكبير 《للإمام البخاري (تههبهـ)، ط: (بدون)، دار الكتب العلمية - بيروت.

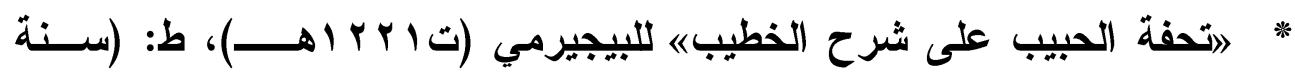

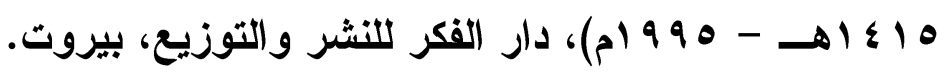

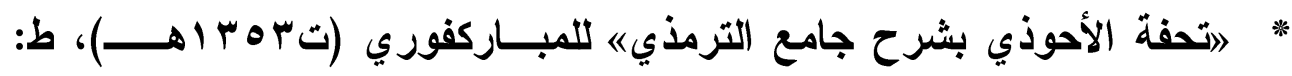

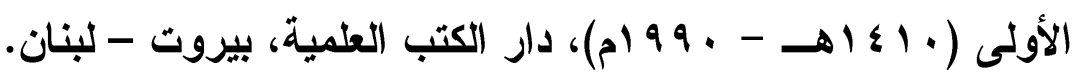

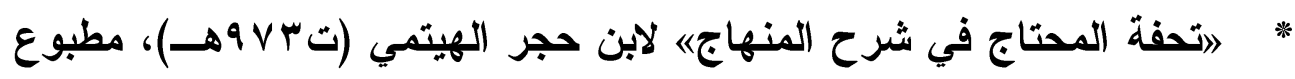

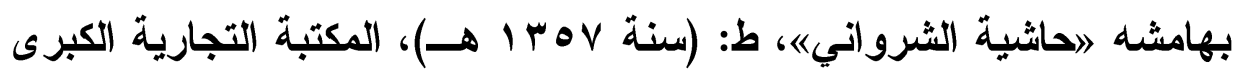
- القاهرة.

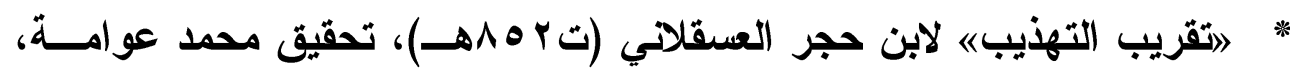

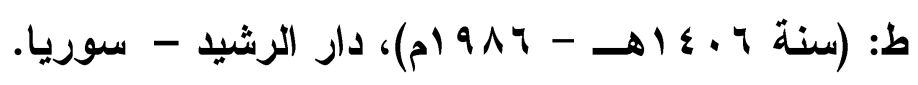

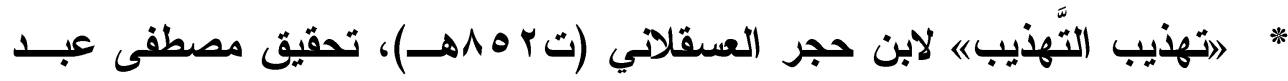

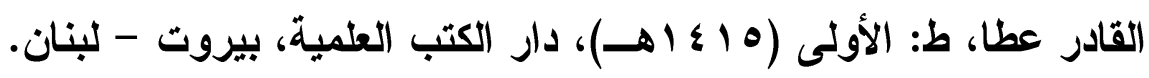

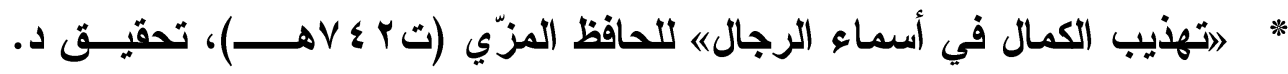

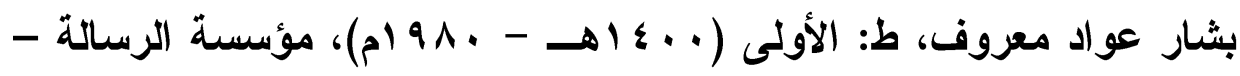
بيزوت.

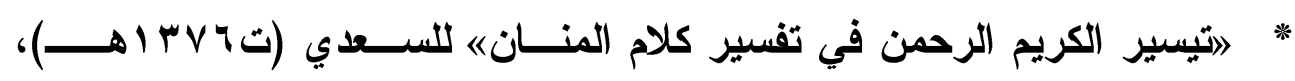

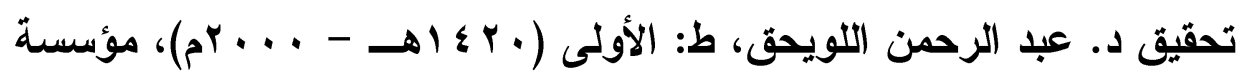

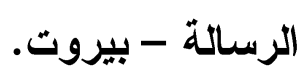

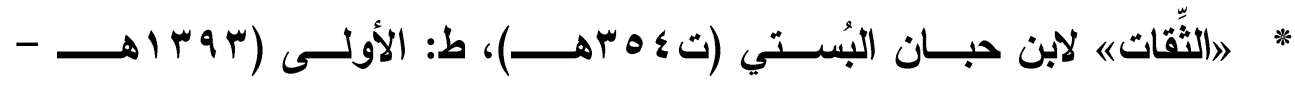

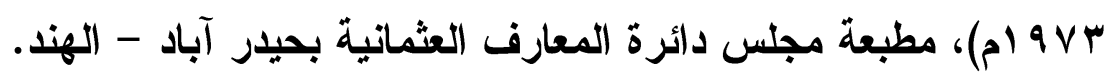


ضجعة الفــجر : مفهومها - صفتها - محلها - حكمها

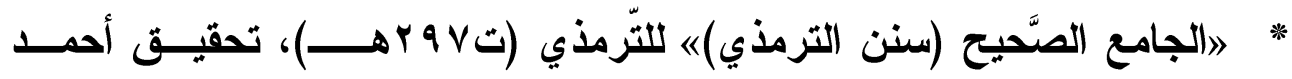
شاكر، ط: (بدون)، دار الكتب العلمية - بيروت - لبنان.

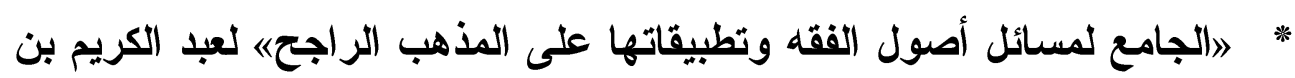

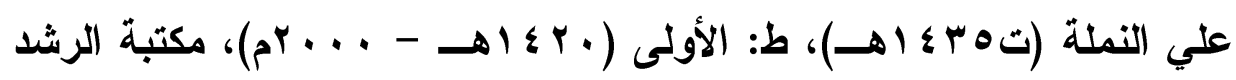

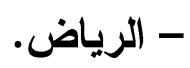

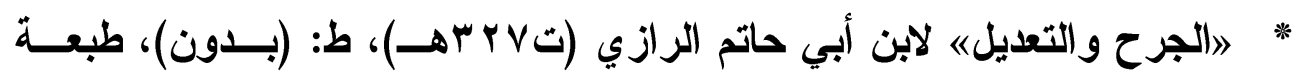
مجلس دائرة المعارف العثمانية بحيدر آباد الاكن - الهند.

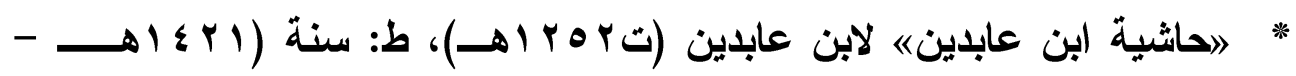

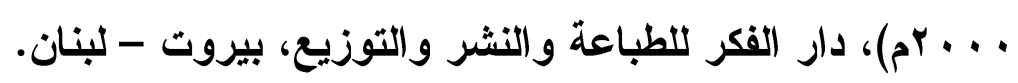

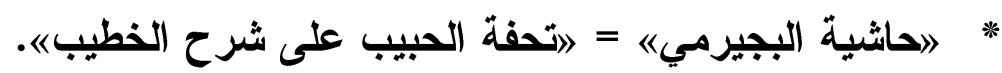

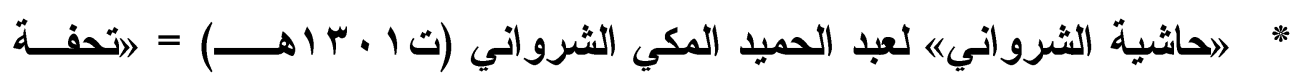
المحتاج في شرح المنهاجه.

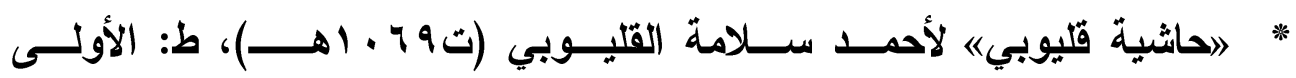

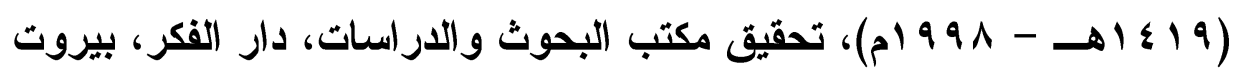
- لبنان -

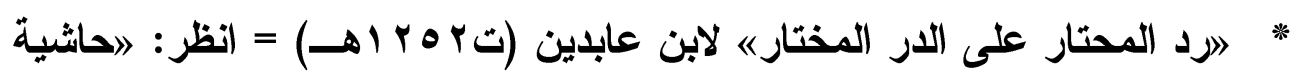
(ابن عابدين).

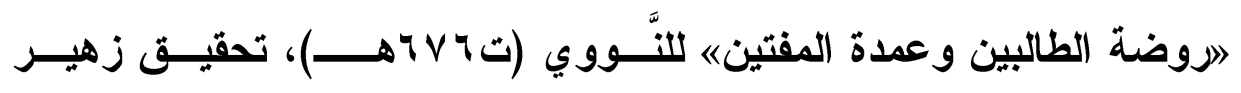

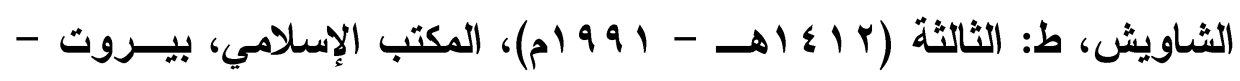
لبنان.

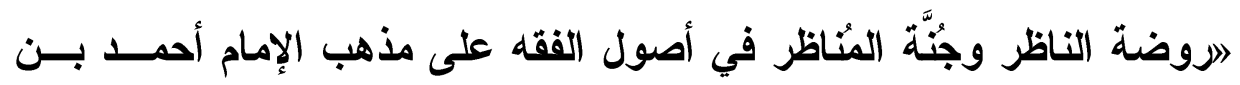

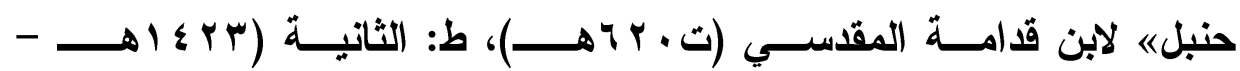


ضجعة الفــجر : مفهومها - صفتها - محلها - حكمها

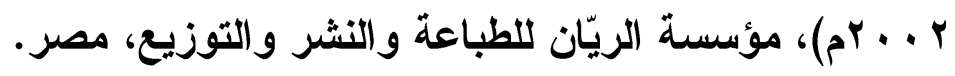

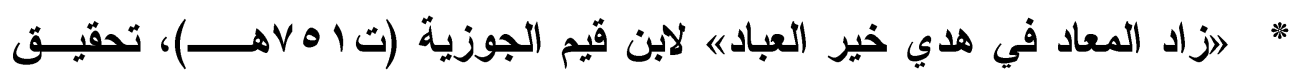

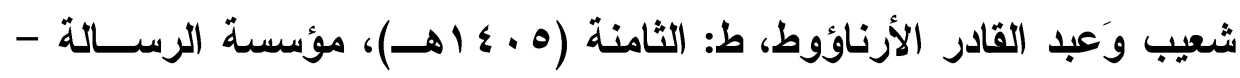

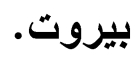

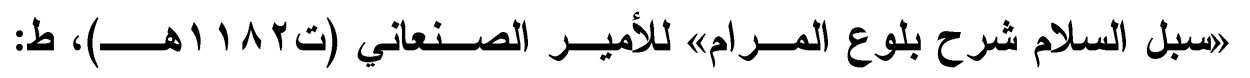

$$
\text { (بدون)، دار الحديث - القاهرة. }
$$

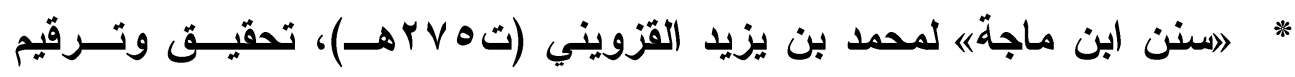
محمد فؤاد عبد الباقي، ط: (بدون)، دار إحياء الكتب العربية.

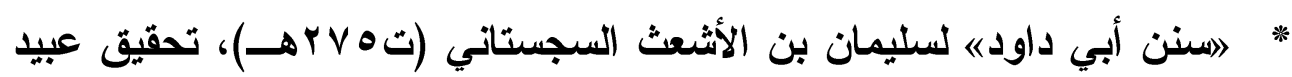

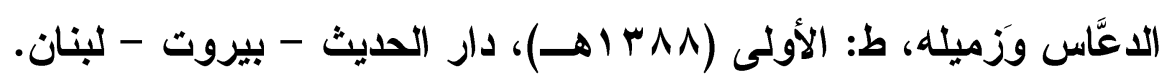

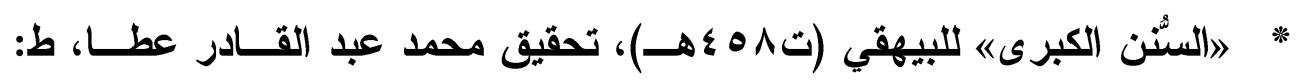

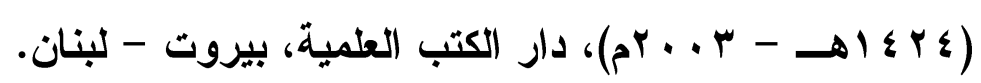

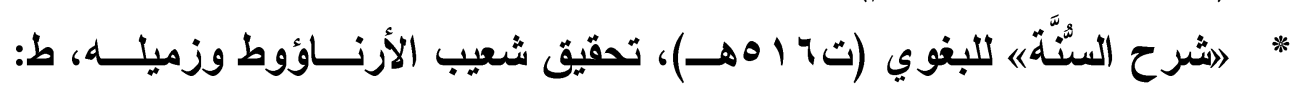
الثانية (r • ع 1)، المكتب الإسلامي، بيروت - لبنان.

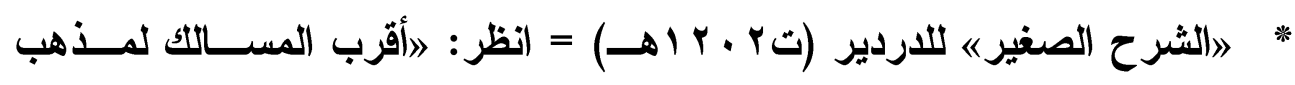
الإمام مالكأك.

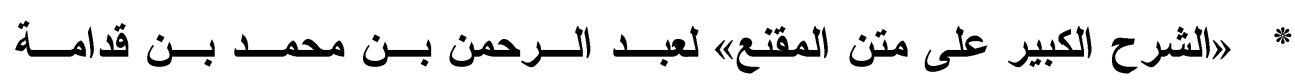

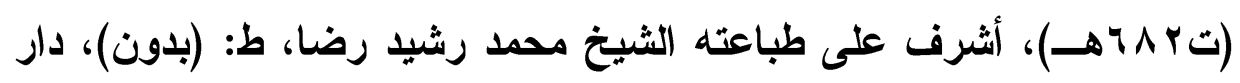
الكتاب العربي للنشر والتوزيع، بيروت - لبنان.

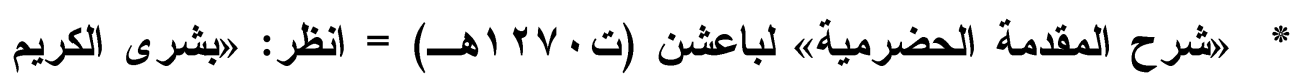
بشرح مسائل التعليمه. " * شرح منتهى الإرادات المسمَّى (دقائق أولي النُهى لشرح المنتهى) لمنصور 
ضجعة الفــجر : مفهومها - صفنها - محلها - حكمها

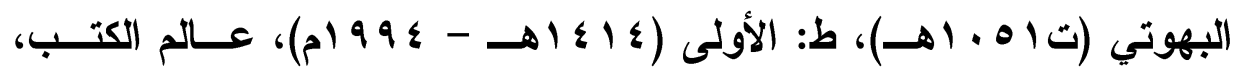
بيروت - لبنان.

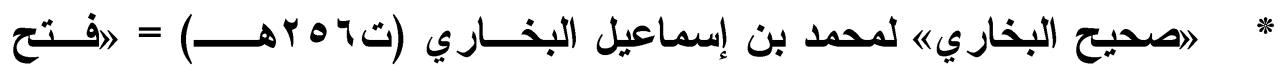

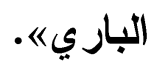

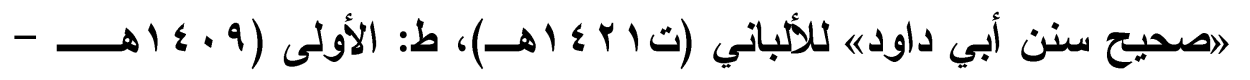

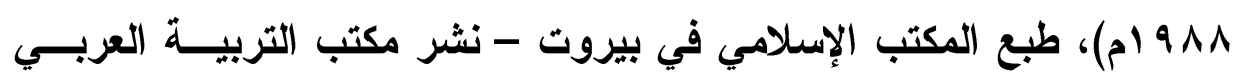

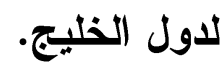

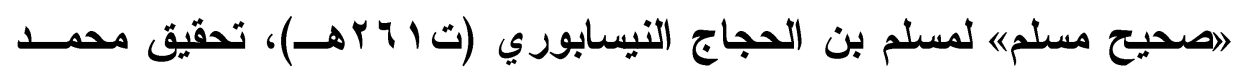
فؤاد عبد الباقي، ط: (بدون)، دار إحياء التراث العربي، بيروت - لبنان.

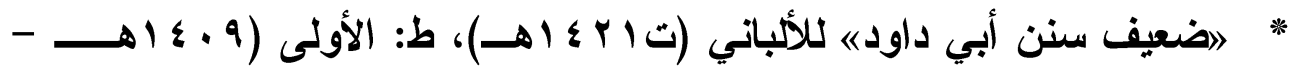
1911 ام)، طبع المكتب الإسلامي في بيروت - نشر مكتب التربيـة العربــي لاول الخليج.

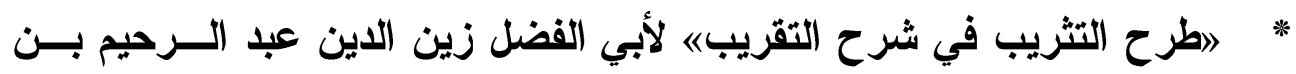

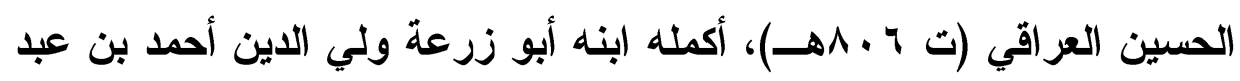

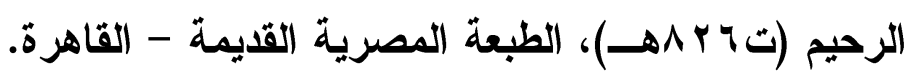

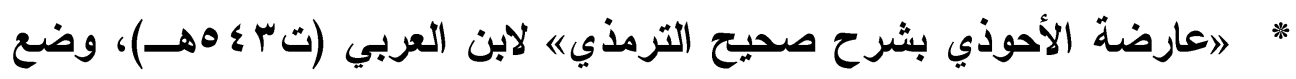

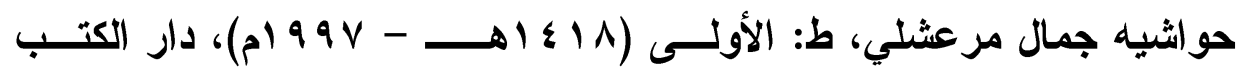
العلمية، بيروت - لبنان.

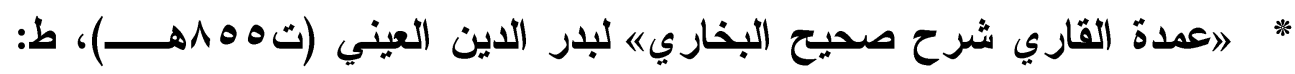
(باون)، دار إحياء التراث العربي - بيروت. 


$$
\text { ضجعة الفـــر : مفهومها - صفتها - محلها - حكمها }
$$

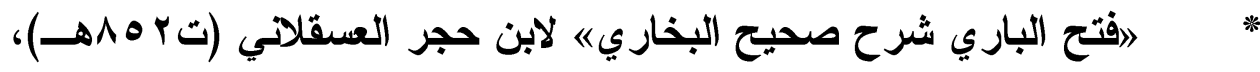
ترقيم وتتظيم محمد فؤاد عبدالباقي، الطبعة السلقية، الناشر دار المعرفة للطباعة

$$
\text { والنشر، بيروت - لبنان. }
$$

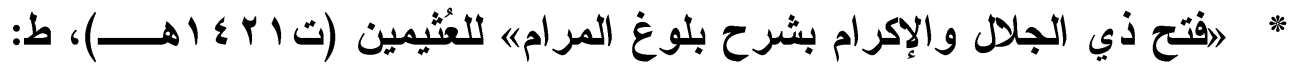
الأولى (q צ أهـ - ^ . . rم)، مدار الوطن للنشر، الرياض - السعودية.

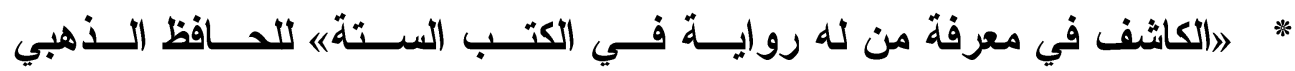

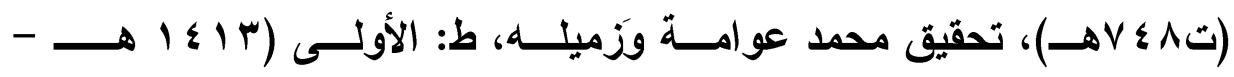
r 9 ام)، دار القبلة للثقافة الإسلامية، مؤسسة علوم القرآن - السعودية.

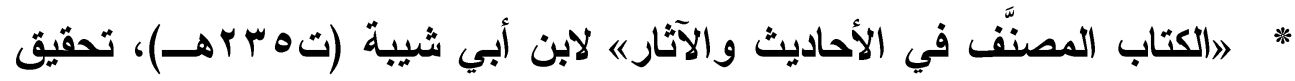
كمال يوسف الحوت، ط: الأولى (9 ، ع اهـ)، مكتبة الرشد، بيروت - لبنان.

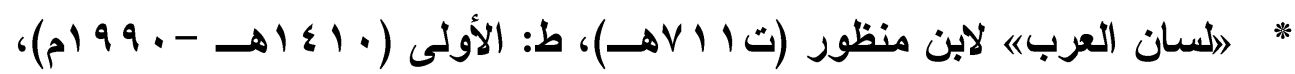
دار صادر - بيزوت.

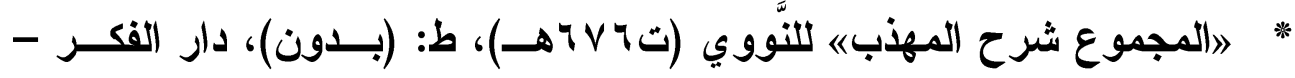

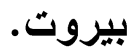

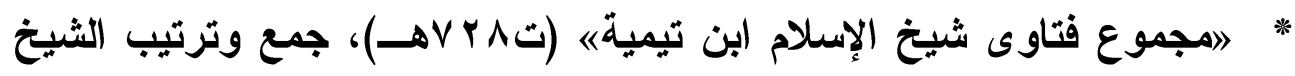
عبد الرحمن بن محمد ابن قاسم، ط: (بدون)، مصورة عن الارار المصرية.

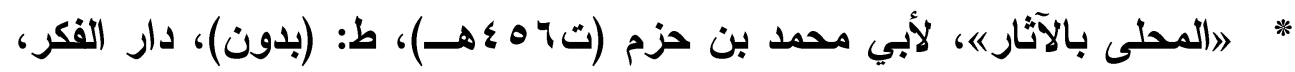

$$
\text { بيروت - لبنان. }
$$

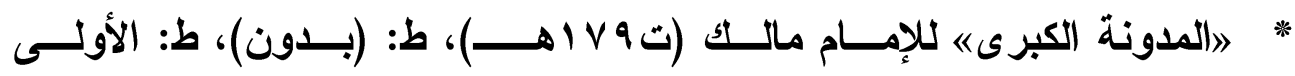

$$
\text { (10 أهـ - ع } 9 \text { (م)، دار الكتب العلمية، بيروث - لبنان. }
$$

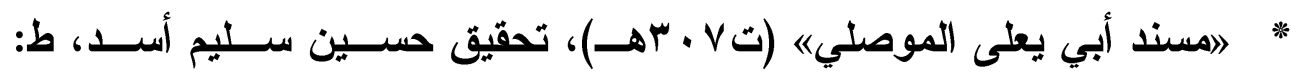

$$
\text { الأولى (ع +ع اهـ - ع } 9 \text { ام)، دار المأمون للتراث - سوريا. }
$$




$$
\text { ضجعة الفـــر : مفهومها - صفتها - محلها - حكمها }
$$

* "المصنَّفِ لعبد الرزاق الصنعاني (ت ا ا بهـ)، تحقيـق حبيـب الــرحمن الأعظمي، من منشورات المجلس العلمي، بدون طبعة وتاريخ. * 》المغني في الضُّعفاء) للحافظ الأهبي (تى ع Vهـ)، تحقيق حازم القاضي، ط: الأولى (ع + ع اهـ - 99 ام)، دار الكتب العلمية - بيزوت. " * أصول الفقه على منهج أهل الحديث) لزكريا بن غلام قادر الباكسـتاني

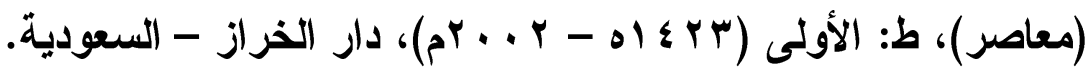

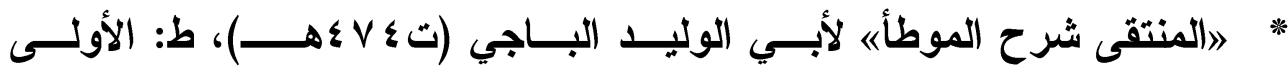
( ) * مواهب الجليل في شرح مختصر خليله للحطَّب الرعيني (ت ع هوهـ)، ط: دار الفكر للنشر والتوزيع، بيروت.

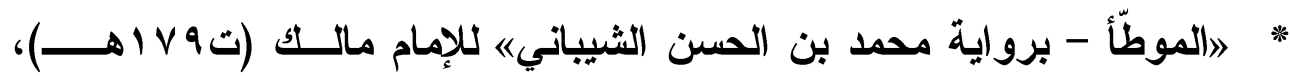
تحقيق عبدالوهاب عبد(للطيف، ط: (بلون)، المكتبة العلمية، بيروت.

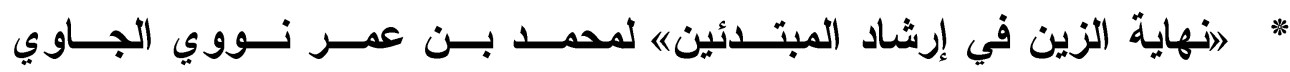
(ت ا اس اهـ)، ط: الأولى (باون تاريخ)، دار الفكر للتشر والتوزيع، بيروت.

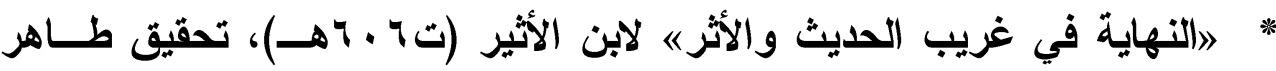
أحمد الزاوي وزميله، ط: (بلون)، المكتبة العلمية - بيروث. * "نهاية المحتاج شرح المنهاجه للرملي (ت ع . . اهـ)، ط: سنة (ع . ع اهـ - ع 9 (م)، دار الفكر للطباعة والنشر والتوزيع، بيروت - لبنان.

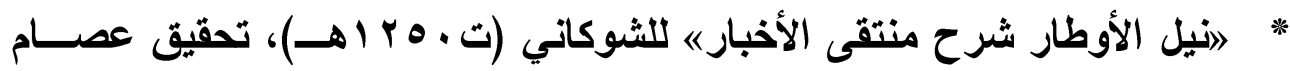

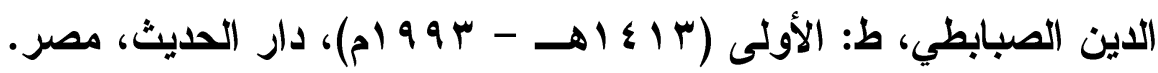




$$
\text { ضجعة الفـــر : مفهومها - صفتها - محلها - حكمها }
$$

فهرس الموضوعات

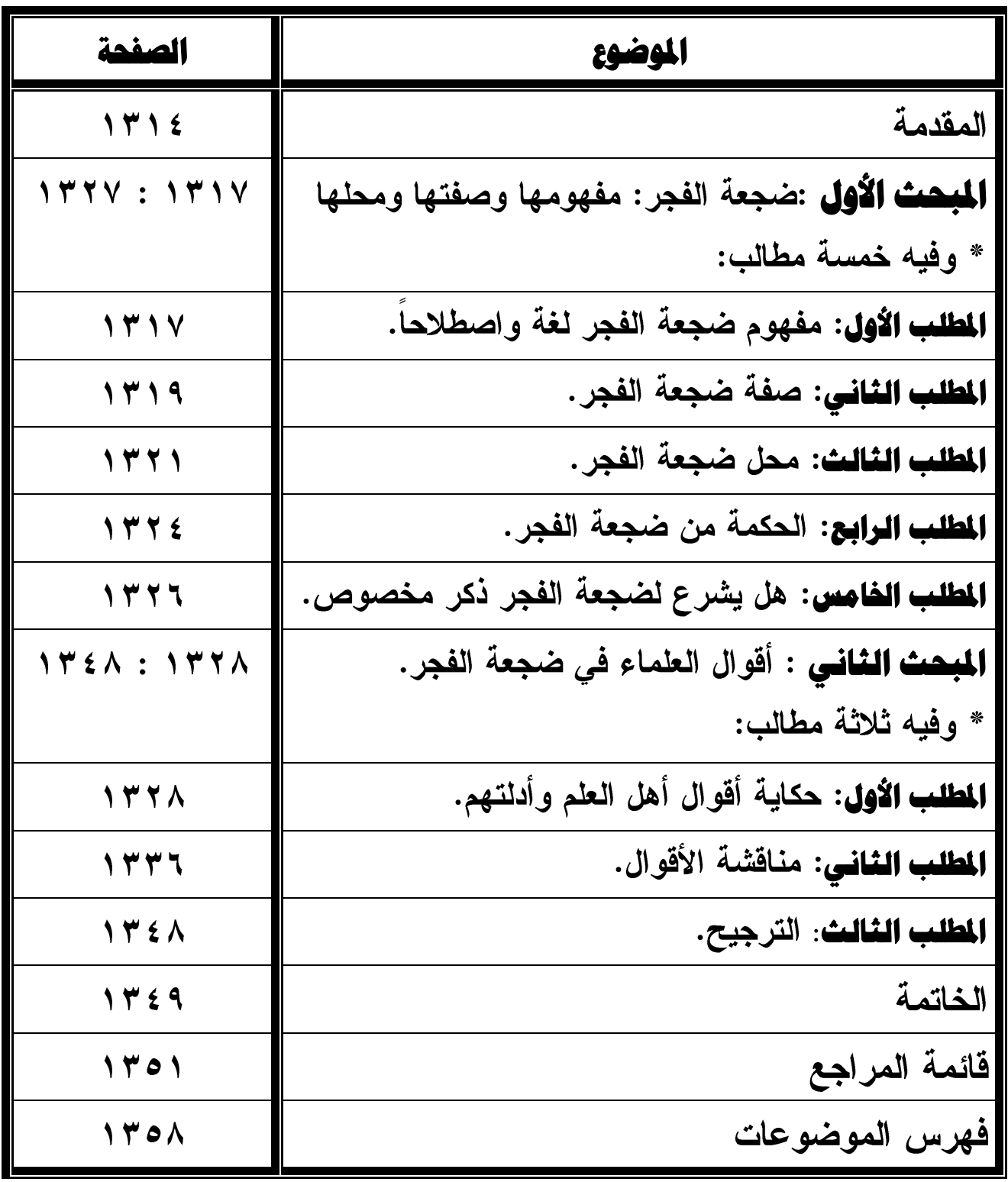

